\title{
Essay
}

\section{The Game's the Same: Why Gambling in Cyberspace Violates Federal Law}

\author{
Bruce P. Keller ${ }^{\dagger}$
}

\section{INTRODUCTION}

For more than a century, Americans have believed that the social ills fostered by gambling outweigh its recreational value. ${ }^{1}$ As a result, gambling has been extensively regulated in order to restrict access to, and control the operation of, legalized gambling facilities. ${ }^{2}$

These restrictions, however, have not diminished gambling's popularity. ${ }^{3}$ Moreover, significant technological developments, most notably the Internet, threaten to circumvent the current regulatory approach in ways that were unimaginable just a few years ago. Unlike brick-andmortar casinos, the action at "virtual casinos" and in other forms of online

$\dagger$ Partner, Debevoise \& Plimpton, New York, New York. The author thanks R. Townsend Davis, Jr., a Debevoise associate, for his help in conceptualizing this Essay, and Peter Johnson, also a Debevoise associate, for his enormous assistance in researching and editing it. Debevoise \& Plimpton represents several professional sports leagues, which have a decided interest in curbing the spread of Internet gambling.

1. See generally Valley Broad. v. United States, 107 F.3d 1328, 1331-32 (9th Cir. 1997) (acknowledging suppression of gambling's social ills as a legitimate governmental interest), cert. denied, 118 S. Ct. 1050 (1998); Players Int'l v. United States, 988 F. Supp. 497, 502 (D.N.J. 1997) (same). In addition to the links to crime so often depicted in popular culture, see, e.g., NICHOLAS PILEGGi, CASINO: LOVE AND HONOR IN LAS VEgAS 177-80 (1995) (detailing the links between gambling and both organized and unorganized crime), these problems include harms to the individual gambler, such as gambling addiction and its fallout-family abuse, workplace abuse, tax evasion, absenteeism, embezzlement, etc. See infra notes 23, 118-138 and accompanying text.

2. See infra notes 120-128 and accompanying text.

3. See TIMOTHY L. O'BRIEN, BAD BET: THE INSIDE STORY OF THE GLAMOUR, GLITZ, AND DANGER OF AMERICA's GAMBLING INDUSTRY 4 (1998) (asserting that, judged by the estimated $\$ 586.5$ billion spent in 1996 , legal "gambling is now more popular in America than baseball, the movies, and Disneyland-combined"). 
gambling ${ }^{4}$ is nonstop and accessible to anyone with Internet access. ${ }^{5}$ Bets can be placed anonymously or pseudonymously, regardless of the bettor's age, sobriety, or finances. Moreover, unlike lawful domestic gambling operations, many Internet gambling sites operate from servers in foreign countries that are unsupervised by U.S. government regulators.

The sudden and ready accessibility of Internet gambling has the potential to turn every home and office into a gambling parlor. Such widespread, unsupervised, and unregulated access, however, is completely inconsistent with a regulatory model that frowns on teenagers playing lotteries or entering casinos. ${ }^{6}$ Thus, the government's interest in regulating Internet gambling is at least as strong as, if not stronger than, its interest in regulating gambling in its traditional forms. ${ }^{\text {? }}$

There are, however, at least two related schools of thought rejecting this view. First, many commentators believe that the unique attributes of the Internet, not the least of which is its inherently transborder nature, require it to be treated as a separate and sovereign jurisdiction where traditional legal approaches should not apply. ${ }^{8}$

Second, operators of online gambling sites offer a specific variation on this theme. They maintain that they escape U.S. law by locating their server and related operations offshore-in countries such as Belize, Curaçao, and

4. These include sports gambling and online lotteries. See 1 ANTHONY CABOT, THE

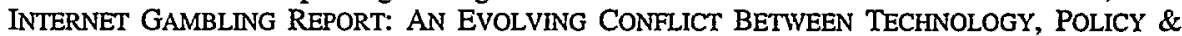
LAW 28-31 (1997).

5. At least some gambling sites appear to be covered by commercially available filtering software. That technological fix, however, not only requires that the user install such software, but also offers only a rudimentary, pro forma protection against use by minors and other problem gamblers. Jay Cohen has testified that his casino "is registered with Cybersitter, NetNanny, and Surf Watch to ensure that children are kept out of our site." The Internet Gambling Act of 1997: Hearing on S. 474 Before the Subcomm. on Tech., Terrorism, and Gov't Info. of the Senate Comm. on the Judiciary, 105th Cong., 1st Sess. 42 (1997) (statement of Jay Cohen, President \& CEO, World Sports Exch.) [hereinafter Kyl Bill Hearing]. In acknowledging that these "controls require parents to be responsible as well," however, he admits that gambling sites have no way of identifying their customers. Id.

6. See, e.g., MO. REV. STAT. ANN. $\S 313.817$ (West 1994) (restricting casino gambling to persons aged 21 and older); NEV. REV. STAT. ANN. § 463.350 (Michie 1994) (same).

7. For example, Louisiana law provides:

The legislature has expressed its intent to develop a controlled well-regulated gaming industry.... The legislature further recognizes that it has an obligation ... to protect its citizens, and in particular its youngest citizens, from the pervasive nature of gambling which can occur via the Internet and the use of computers connected to the Internet.... Gambling which occurs via the Internet embodies the very activity that the legislature seeks to prevent.

LA. REV. STAT. ANN. § 14:90.3 (West Supp. 1998) (emphasis added). But cf. infra note 140 (suggesting that the imprecise language of the Louisiana statute may make it vulnerable to a constitutional challenge).

8. This argument has been made with particular vigor in the intellectual property context. See, e.g., John Perry Barlow, The Economy of Ideas, WIRED, Mar., 1994, at 84, 85 (arguing that traditional copyright law is obsolete in cyberspace). But cf. Panavision Int'l v. Toeppen, 141 F.3d 1316, 1321-22 (9th Cir. 1998) (asserting jurisdiction over a trademark infringement suit despite the defendant's claim that "the injury occurred in cyberspace"). 
Antigua-making it irrelevant that their American customers are playing in Peoria. As one Internet gambling operator has put it:

All wagers take place in Antigua on our server. No money is transferred on a bet by bet basis. People must open accounts and wager from their accounts. When players bet they are directing a foreign transaction, no different than moving money from one offshore business to another... The bet takes place in Antigua. The money is already here.... They are making a virtual visit to Antigua. ${ }^{9}$

These arguments are echoed in various law review articles that call for the creation of new Internet legal models. Commentators raise the concern that, without such a new framework, the Internet's transborder nature and unique mores virtually ensure that no "stable body of jurisprudence" can be developed. ${ }^{10}$

The weakness underlying all of these arguments is that they accept too literally the concept of "cyberspace" as an actual "place." In so doing, they embrace a metaphor that is far from exclusive and, in many ways, far from appropriate. For example, competing with the term "cyberspace" is the description of the Internet as an "information superhighway." 11 Other metaphors and analogies abound. ${ }^{12}$

9. Kyl Bill Hearing, supra note 5, at 41 (statement of Jay Cohen, President \& CEO, World Sports Exch.); see also O'BRIEN, supra, note 3 at 13 (" "The Internet is a global communications technology not bound by the laws or control of any one government. Internet casinos are only bound by the laws of their host country. Placing bets cannot be illegal because, despite their origination, bets will technically be placed on the computer at our off-shore land-based casino site that is legally licensed and taxed by the host government." (quoting a statement from World Wide Web Casinos's Internet site)).

10. Greg Y. Sato, Note, Should Congress Regulate Cyberspace?, 20 HASTINGS COMM. \& ENT. L.J. 699, 710 (1998); see also David R. Johnson \& David Post, Law and Borders-The Rise of Law in Cyberspace, 48 STAN. L. REV. 1367, 1367 (1996) (arguing that cyberspace should be thought of as a distinct place because of its inherent lack of borders and transnational nature); Lawrence Lessig, The Path of Cyberlaw, 104 YALE L.J. 1743, 1743 (1995) (raising the question, "Is Cyberspace really anything new?"); Lawrence Lessig, The Zones of Cyberspace, 48 STAN. L. REV. 1403, 1403 (1996) (answering the question, at least in part, by noting that many cyberspace activities have consequences in physical space in the same way that real world acts do); Jonathan Zittrain, The Rise and Fall of Sysopdom, 10 HARV. J.L. \& TECH. 495, 506-09 (1997) (offering a compelling explanation of why procedural rules and substantive causes of action often do not fit well when applied to the vigorous exchange of views often encountered online); Dan L. Burk, Jurisdiction in a World Without Borders, 1 VA. J.L. \& TECH. 3, 6 <http://scs.student.virginia.edu/ $\sim$ vjolt/graphics/vol1/home_art3.html> (1997) ("The geographic transparency of the Internet may well place... adjudication of transborder disputes outside of any jurisdictional analysis yet contemplated by territorially-bound law.").

11. See, e.g., Clay Calvert, Regulating Cyberspace: Metaphor, Rhetoric, Reality, and the Framing of Legal Options, 20 HASTINGS COMM. \& ENT. L.J. 541, 542, 544 (1998) (pointing out that the phrase "information superhighway," which Vice President Gore claims to have coined, is an overused metaphor that is not particularly apt).

12. See, e.g., Reno v. ACLU, 117 S. Ct. 2329, 2344 (1997) ("Through the use of chat rooms, any person with a phone line can become a town crier with a voice that resonates farther than it could from any soapbox. Through the use of Web pages, mail exploders, and newsgroups, the 
As Professor Clay Calvert has recognized, one of the problems with using metaphors to describe online activities is that the metaphor can replace the reality and thus "frame our thinking too narrowly." 13 Thus, although it may be colorful, it is not analytically useful to think of the Internet as a transportation vehicle in which one makes "virtual" voyages. ${ }^{14}$ To the contrary, the Internet is an earthbound network of interconnected computers, each with a specific physical location, connected by a physical telecommunications backbone. One no more makes a "virtual visit" when using the Internet than when telephoning long distance.

Equally fanciful is the concept of the Internet as its own, ethereal jurisdiction. "Cyberspace," after all, is not a real place, but a term coined in a science fiction novel. ${ }^{15}$ For all of its unique attributes, it "exists" as a separate jurisdiction only in the sense that Never-Never Land does. ${ }^{16}$

Rather than debate which of several competing metaphors may be appropriate to describe online activities, it is more appropriate to step back and inquire, in a media-neutral manner, whether the particular activity under review takes on a different complexion when it occurs over the Internet as opposed to other contexts. By eschewing all labels, one avoids having to choose among them. By focusing on the underlying activity, one reduces the risk of being trapped in a confining analogy. By frankly assessing the conduct at issue, without undue regard for the medium through which it is conducted, one gets to the heart of the policy concerns that led to the creation of the applicable legal rule.

Internet gambling offers an excellent test case for this approach because, although the Internet may change the mechanics of gambling by a considerable degree, it does not change the nature of gambling itself. Moreover, the differences in mechanics, which stem from the pervasive and instantaneous nature of this medium, only compound the problems generally associated with gambling. As Professor I. Trotter Hardy has noted, notwithstanding the unique nature of some acts in cyberspace, the Internet presents no new legal issues when it is being used "simply [as] a medium of

same individual can become a pamphleteer."); American Libraries Ass'n v. Pataki, 969 F. Supp. 160, 161 (S.D.N.Y. 1997) (raising questions of whether "the Internet is more like a television? a radio? a newspaper? a 900-line? a village green?").

13. Calvert, supra note 11, at 565.

14. See Playboy Enters. v. Chuckleberry Publ'g, 939 F. Supp. 1032, 1039 (S.D.N.Y. 1996) (expressly rejecting the contention that permitting U.S. residents to access the adult Web site "Playmen," based in Italy, was the equivalent of flying to Italy to purchase a copy of Playmen magazine).

15. William GibSON, NEUROMANCER 51 (1985).

16. See J.M. BARRIE, PETER PAN (1928); see also Steven R. Salbu, Who Should Govern the Internet?: Monitoring and Supporting a New Frontier, 11 HARV. J.L. \& TECH. 429, 455 (1998) (criticizing the "so-called cyber-libertarian ideal, which takes the term "cyberspace' too literally"); Stephan Wilske \& Teresa Schiller, International Jurisdiction in Cyberspace: Which States May Regulate the Internet?, 50 FED. COMM. L.J. 117, 124 (1997) (arguing that "it is hard to maintain that the Net is some kind of free city in the sky"). 
direct communication between people-much like the telephone, mail or fax." ${ }^{17}$ Internet gambling readily falls into that category. For the purposes of federal antigambling laws, it is the 1990s equivalent of using the telephone to play the numbers or place bets. It is a type of online activity whose medium does not affect the legal consequences. Moreover, it illustrates why certain laws, both criminal and civil, are properly applied in a media-neutral fashion.

Most articles on Internet gambling disagree, but fail to identify what it is about long-distance gambling online that distinguishes it from longdistance gambling via the mail or telephone and makes it incapable of regulation. Most focus almost exclusively on jurisdictional issues or perceived enforcement problems, leading them to conclude that applying United States laws to prevent online gambling operators from transacting business with U.S. citizens is at least unwise, if not impossible. ${ }^{18}$

This Essay disagrees. Troubling policy issues lurk in the assumption that gambling in cyberspace, along with countless other Internet issues, requires a new legal regime. These issues are broader than the problems associated with the proliferation of gambling. First, accepting these

17. I. Trotter Hardy, The Proper Legal Regime for "Cyberspace," 55 U. PITT. L. REV. 993, 1000 (1994). In this context, references to the telephone or fax are not useful analogies because the Internet has directly replaced those methods of communication. One of the problems with other Internet analogies is that they do not give sufficient recognition to the Internet's growing role as a substitute for telephony and other means of electronic communication. See, e.g., Internet Telephony: Growing up, ECONOMIST, May 2, 1998, at 56 (estimating that by 2003 , " $25 \%$ of international call minutes worldwide will be made over the Internet"); see also Reno v. ACLU, 117 S. Ct. 2329, 2334 (1997) ("The Internet is a 'unique and wholly new medium of worldwide human communication." (quoting ACLU v. Reno, 929 F. Supp. 824, 844 (E.D. Pa. 1996))).

18. Commentators on the subject have tended to emphasize the international issues raised by Internet gambling. See, e.g., Harley J. Goldstein, On-Line Gambling: Down to the Wire?, 8 MARQ. SPORTS L.J. 1, 51 (1997) (contending that because cyberspace should be treated as its own legal regime, to properly regulate Internet gambling without creating an international conflict of laws, "a regulatory framework must be formed on the international level"); John Edmund Hogan, Comment, World Wide Wager: The Feasibility of Internet Gambling Regulation, 8 SETON HALL CONST. L.J. 815, 827 (1998) ("Internet gambling is far less compatible with conventional legal methodology due to the lack of territorial containment and... effective enforcement...."). Others have expressed concerns that the practical enforcement problems spawned by Internet gambling create a reason not to prohibit Internet gambling, but to legalize and regulate it. See $\mathrm{Kyl}$ Bill Hearing, supra note 5, at 47 (statement of Sue Schneider, Chairman, Interactive Gaming Council) ("Internet gambling is inevitable.... [T]o prohibit this form of home entertainment is simply not realistic."); Nicholas Robbins, Baby Needs a New Pair of Cybershoes: The Legality of Casino Gambling on the Internet, 2 B.U. J. SCI. \& TECH. L. 7, 59 (1996) (concluding that if technology outpaces law enforcement, "America may have no choice" but to live with statesanctioned online gambling); Seth Gorman \& Antony Loo, Comment, Blackjack or Bust: Can U.S. Law Stop Internet Gambling?, 16 LOY. L.A. ENT. L.J. 667, 708-09 (1996) (suggesting that "[e]ncryption, digital communications, electronic cash, and tracing difficulties make enforcement of the current statutes against [Internet] casinos virtually impossible" and that applying "antiquated notions of personal jurisdiction to the borderless Internet" may be difficult); Scott M. Montpas, Comment, Gambling On-Line: For a Hundred Dollars, I Bet You Government Regulation Will Not Stop the Newest Form of Gambling, 22 U. DAYTON L. REV. 163, 184-85 (1996) (asserting that "the nature of the Internet renders isolated United States' laws unenforceable to a large extent" and that legislators should collaborate with foreign governments to establish a uniform policy that facilitates self-regulation). 
arguments requires a departure from existing case law upholding over one hundred years of congressional efforts that respond to developments in communications technology when they threaten the federal regulatory approach to interstate and international gambling. ${ }^{19}$ Second, a "hands off" approach sends the wrong message to courts that otherwise must grapple, and by and large have done so successfully, with new issues created by the Internet and other digital technologies. ${ }^{20}$

Third, and perhaps most disturbing, waiting for the development of a new legal regime capable of resolving "all issues Internet" would require turning a blind eye to the immediate and pervasive nature of the nonInternet contacts these so-called "offshore" sites have with the United States. Some sense of these contacts can be gained from reviewing the complaints filed in the series of precedent-setting prosecutions commenced in March 1998 against twenty-one Internet sports gambling sites. ${ }^{21}$ In a direct challenge to Internet gambling operators' contentions that they avoid violating federal antigambling laws by locating their operations offshore, the United States Attorney for the Southern District of New York has alleged that these Web sites violate the Wire Wager Act. ${ }^{22}$ The allegations detail the ubiquitous nature of the contacts those purportedly offshore operations have with U.S. citizens and how similar these transactions are to gambling transactions previously conducted by mail and telephone.

Finally, measured against brick-and-mortar casinos, Internet gambling has a greater potential to exacerbate the abuses associated with addictive or underage gambling and appears to pose a much higher risk to society. The anonymity and ubiquity of Internet gambling, coupled with its reliance on credit cards to foster long-distance betting, increases these risks, particularly given that video gambling devices have been characterized

19. See infra notes 76-104 and accompanying text.

20. Many courts have successfully applied existing legal doctrine to Internet-related disputes. See, e.g., Panavision Int'1 v. Toeppen, 141 F.3d 1316, 1324-26 (9th Cir. 1998) (ruling that defendants' intent to sell an Internet domain name constitutes a "commercial use" for the purposes of the federal Trademark Dilution Act); Tasini v. New York Times, 972 F. Supp. 804, 818-21 (S.D.N.Y. 1997) (applying the concept of "media-neutrality" to conclude that a copyright holder's right to publish a "revision" of collective works includes digital, on-line revisions, even if the digital nature of the medium resulted in differences from the original print publications); Religious Tech. Ctr. v. Netcom On-Line Communication Servs., 907 F. Supp. 1361 (N.D. Cal. 1995) (declining to adopt a purely literal approach to the Copyright Act and concluding that an online service provider was not contributorily or vicariously liable for users' posting of copyrighted material, if the provider had no actual knowledge of infringing acts). I previously have commented on the importance of creative uses of common and statutory law to resolve technology disputes given the time it takes to achieve more comprehensive legislative solutions. See Bruce P. Keller, Condemned To Repeat the Past: The Reemergence of Misappropriation and Other Common Law Theories of Protection for Intellectual Property, 11 HARV. J.L. \& TECH. 401 (1998).

21. See infra notes $105-116$ and accompanying text.

22. 18 U.S.C. $\$ 1084$ (1994); see infra notes $105-116$ and accompanying text. 
as the most addictive form of gambling. Some call them the "crack cocaine" of the gambling world. When the personal computer becomes a video gambling machine, the problem gambler will confront a powerful temptation in the next room 24 hours a day ... [A]s Internet gambling grows, society stands to suffer from more gambling addiction. ${ }^{23}$

In short, there are powerful policy and process reasons why it makes sense to prosecute those who entice and enable U.S. citizens to gamble online. Even after giving due deference to the nearly unanimous line of contrary commentary, this Essay concludes: (1) there is nothing unique about Internet gambling that should lead the federal government to abandon its traditional protective role in this area; ${ }^{24}$ and (2) there is no reason why existing gambling laws cannot be applied online as successfully as other laws have been.

Part II of this Essay gives a brief overview of U.S. gambling laws, including the role of federal law in maintaining the integrity of each state's approach to gambling. It focuses on the Wire Wager Act, which has become the federal government's main weapon against Internet gambling. Part III details various failed attempts to challenge federal antigambling laws, leading to Part IV, which describes the recent prosecutions of Internet gambling site operators under the Wire Wager Act. Part V analyzes the societal concerns that necessitate regulation of Internet gambling and discusses why the appropriate application of federal law avoids both constitutional and practical concerns. Finally, Part VI concludes by emphasizing how laws governing real space can be applied successfully to cyberspace in a media-neutral way.

23. Kyl Bill Hearing, supra note 5, at 11 (statement of James E. Doyle, Att'y Gen., State of Wis.). Largely because of the dangers that Internet gambling poses to minors and problem gamblers, the National Gambling Impact Study Commission is expected to "seek a broad ban on online gambling when it issues its report in June [1999]." Online Gambling Ban To Be Recommended When Gaming Study Panel Issues Its Report, 4 Elec. Commerce \& L. Rep. (BNA) 261, 261 (Mar. 24, 1999) [hereinafter Online Gambling Ban]. "[C]reated by Congress as an independent body," the Commission will "conduct a comprehensive study of the social and economic impacts of gambling in the United States." Id. at 262.

24. See Greater New Orleans Broad. Ass'n v. United States, 69 F.3d 1296, 1300 (5th Cir. 1995) (ruling that the federal government has an interest in protecting its citizens from gambling that is independent of states' interests in doing so), cert. granted, 119 S. Ct. 863 (1999); see also Online Gambling Ban, supra note 23, at 262 (stating that the recommendation by the Commission's Regulation, Enforcement, and Internet Subcommittee "was prompted by state concerns that the federal government should take the lead in regulating Internet gambling"). 


\section{AN OVERVIEW OF U.S. GAMBLING LAWS}

\section{A. State Laws}

Gambling legislation is largely a matter of state law and, as a result, varies considerably, running from prohibition to regulation to taxation to the even more remunerative scheme of outright cooption, most notably in the form of state-run lotteries. ${ }^{25}$ Utah, for example, allows its citizens no access to gambling-hosting even a private poker game is outlawed. ${ }^{26}$ Conversely, Nevada, Utah's next door neighbor, is well-known for taking quite a different approach. ${ }^{27}$

Private lotteries - a form of gambling traditionally defined as games in which people pay consideration for the opportunity to win a prize based on chance rather than skill ${ }^{28}$ - are unlawful in every state. ${ }^{29}$ Filling the void, however, are the thirty-seven states and the District of Columbia that run their own lotteries, on which people bet thirty-five billion dollars per year. ${ }^{30}$ Similarly, although most states prohibit private off-track betting on horse and dog races, a number run their own off-track betting parlors, where total bets exceed over two billion dollars annually. Seven states allow off-track bets to be placed by phone. ${ }^{31}$

25. Cf. Interstate Horseracing Act of 1978, 15 U.S.C. $\$ 3001$ (a)(1)-(2) (1994) ("The Congress finds that... the states should have the primary responsibility for determining what forms of gambling may legally take place within their borders [and] ... the Federal Government should prevent interference by one State with the gambling policies of another ....").

26. See UTAH CODE ANN. \$76-10-1102 (1953) ("A person is guilty of gambling if he... knowingly permits any gambling to be played, conducted, or dealt upon or in any real or personal property owned, rented, or under the control of the actor, whether in whole or in part."). Hawai' $i$ is the only other state to outlaw all forms of gambling. See HAw. REV. STAT. ANN. \$ 7121223 (Michie 1994) ("A person commits the offense of gambling if he knowingly advances or participates in any gambling activity. ... Gambling is a misdemeanor.").

27. See NEv. REv. STAT. ANN. \$ 463.0129 (Michie 1994) ("The legislature hereby finds, and declares it to be the public policy of this state, that ... [t]he gaming industry is vitally important to the economy of the state and the general welfare of the inhabitants."). See generally O'BRIEN, supra note 3, at 22-57 (describing the evolution of Las Vegas as a gambling mecca).

28. See FCC v. ABC, 347 U.S. 284, 290 (1954).

29. See, e.g., KAN. STAT. ANN. \$ 21-4304(d) (1995) (criminalizing "conducting a lottery, or with intent to conduct a lottery possessing facilities to do so"); MD. ANN. CODE art. $27, \S 356$ (1996) ("No person shall draw any lottery or sell any lottery ticket in this State; nor shall any person sell ... anything by which the vendor or other person promises or guarantees that any particular number, character, ticket or certificate shall in any event or on the happening of contingency entitle the purchaser or holder to receive money, property or evidence of debt.") This was not always the case. Lotteries were quite popular in colonial times and "[s]uch elite Ivy League Universities as Harvard, Yale, Princeton, and Columbia were built in part through lotteries." O'BRIEN, supra note 3, at 158; see also A.R. Spofford, Lotteries in American History, in ANNUAL REPORT OF THE AMERICAN HISTORICAL ASSOCIATION FOR THE YEAR 1892, at 171, $171-95$ (1893) (describing the use of lotteries to fund both public and private works in the colonial and early federal era).

30. See North American Ass'n of State \& Provincial Lotteries, Data Compiled Regarding FY 1998 vs. FY 1997 Lottery Sales and Profits (1998) (on file with The Yale Law Journal).

31. See 1 CABOT, supra note 4 , at 29. 
In recent years, the prospects of gambling as a taxable revenue source, directly or in the form of increased tourism revenues, has proven irresistible to many states. The number of states that permit, regulate, and tax casino or riverboat gambling grew from just two in 1988-Nevada and New Jerseyto twenty-five today. ${ }^{32}$ Today, every state except Utah and Hawai'i has legalized some form of gambling. ${ }^{33}$ It is therefore hardly surprising that, in 1996, legal wagering of all kinds in the United States totaled over $\$ 550$ billion. $^{34}$ In an effort to ensure that some of the social ills linked to gambling are not fostered by these state authorized operations, a number of states specifically require that information about and help for compulsive gambling be published in conjunction with information about state-run lotteries and at state-run gambling sites. ${ }^{35}$ Others allocate a percentage of lottery revenues to Gamblers Anonymous and other treatments for problem gamblers. ${ }^{36}$

\section{B. Federal Laws}

The historical federal response to gambling recognizes that this hodgepodge approach has created wide variations among even neighboring states. As a result, Congress consistently has acted to ensure that neither interstate nor foreign commerce is used to circumvent whatever choices have been made at the state level. ${ }^{37}$ This approach, adopted by Congress "as

32. Twenty-three states allow casino gambling, while two other states host casino "crusies to nowhere," where the gambling takes place in international waters. See National Coalition Against Legalized Gambling, NCALG Fact Sheets: Legalized Gambling Has Rapidly Expanded (visited Feb. 22, 1999) <http://www.ncalg.org/pages/ftshts.htm>.

33. See id; see also Jon Bigness, Companies Place Bets on Internet Gambling, CHI. TRIB., Aug. 25, 1997, at 1, 4 (" [S]ome form of gambling is legal in just about every state and ... more than half of all states have casino establishments ...."). As a result of the Indian Regulatory Gaming Act, 25 U.S.C. $\$ 2701$ (21) (1994), Indian tribes have the right to operate gambling casinos on Indian lands. See id. § 2701(5).

34. See O'BRIEN, supra note 3, at 4; Bigness, supra note 33, at 2.

35. See, e.g., VA. CODE ANN. \$ 58.1-4007.1A (Michie 1997 \& Supp. 1998) ("All lottery tickets printed after July 1, 1997, shall bear a toll-free telephone number for 'Gamblers Anonymous' or other organization which provides assistance to compulsive gamblers."); $i d$. $\$ 59.1-369.3$ ("[L]icensees [shali] post, in a conspicuous place in every place where pari-mutuel wagering is conducted, a sign which bears a toll-free telephone number for "Gamblers Anonymous' or other organization which provides assistance to compulsive gamblers.").

36. See, e.g., IOWA CODE ANN. \$99E.10.1.a (West 1996) ("An amount equal to three-tenths of one percent of the gross lottery revenue shall be deposited in a gamblers assistance fund in the office of the treasurer of the state."). Notwithstanding these programs, it is fair to question the strength of legislative convictions about the evils of gambling in light of the number of states that run lotteries and the numerous exceptions carved out of antigambling states. See, e.g., Pic-A-State Pa., Inc. v. Reno, 76 F.3d 1294, 1303 (3d Cir. 1996) (considering, but ultimately rejecting, the argument that because the majority of states have legalized lotteries, lotteries may not be prohibited on moral grounds); Players Int'l v. United States, 988 F. Supp. 497, 506-07 (D.N.J. 1997) (expressing concern over the manner in which the federal policy of banning certain casino advertising is subverted by numerous exceptions).

37. See, e.g., United States v. Edge Broad., 509 U.S. 418, 421 (1993) (noting that "Congress has, since the early 19th century, sought to assist the States" in their respective efforts). 
early as $1827, "$ has evolved over the years in response to developments in communication and transportation. ${ }^{38}$ These efforts culminated, in the 1960 s, with an approach reflected in the Wire Wager Act, ${ }^{39}$ the statute that most directly precludes efforts to use the Internet to communicate with U.S.based gamblers. ${ }^{40}$

The congressional role has been to prevent interstate commerce from being used to breach the walls states have erected to regulate gambling within their borders. In 1827 , Congress began by targeting the federal government's then most ubiquitous representatives in interstate commerce: postmasters. It prohibited any postmaster from acting "as agent for lottery offices." ${ }^{41}$ A few years later, concerned that even if individual postmasters were not assisting in the promotion of gambling, the mails certainly could be used for that purpose, Congress expanded the prohibition to outlaw any use of the U.S. mail to promote "lotteries ... or other similar enterprises offering prizes of any kind ...." In the 1890 s, when lotteries attempted to circumvent the mailing ban by advertising in newspapers, Congress responded by outlawing the mailing of any newspapers that carried such advertising ${ }^{43}$ and by prohibiting the transportation of lottery tickets in interstate commerce. ${ }^{44}$

Faced with the communications revolution spawned by radio broadcasting, Congress in 1934 criminalized broadcast advertising containing information about commercial lotteries. ${ }^{45}$ The language of this

38. Valley Broad. v. United States, 107 F.3d 1328, 1329 (9th Cir. 1997), cert. denied, 118 S. Ct. 1050 (1998). Interestingly, in the early 1800s, Congress itself improperly authorized the sale of "National Lottery" tickets in states where lotteries are illegal. See Cohens v. Virginia, 19 U.S. (6 Wheat.) 264 (1821) (upholding the indictment in Virginia of agents selling lottery tickets authorized by Congress to raise money for a canal in the District of Columbia and Maryland).

39. 18 U.S.C. $\$ 1084$ (1994).

40. See infra notes $58-75$ and accompanying text.

41. Act of Mar. 2, 1827, ch. 61, § 6, 4 Stat. 238.

42. Act of July 27,1868 , ch. $246, \S 13,15$ Stat. 196.

43. See Anti-Lottery Act of 1890, ch. $908, \& 1,26$ Stat. 465.

44. See id. The current iteration of this prohibition is found at 18 U.S.C. $\$ 1301$ (1994).

45. See Act of June 19, 1934, Pub. L. No. 73-416, ch. 652, §316, 48 Stat. 1064, 1088. The current prohibition on such broadcasts is found at 18 U.S.C. $\$ 1304$. Courts have split on the constitutionality of this prohibition. In United States v. Valley Broadcasting Co., 107 F.3d 1328 (9th Cir. 1997), cert. denied, 118 S. Ct. 1050 (1998), and Players International v. United States, 988 F. Supp. 497 (D.N.J. 1997), the courts determined that the prohibition, as applied to broadcast advertisements in Nevada and New Jersey, respectively, for legal casino gambling, violated the casino operators' First Amendment rights. Both courts based their holdings largely on the exemption from the ban that allows casinos operated on Indian reservations to advertise on television, reasoning that this exemption effectively undercuts the desired effect of the ban. See Valley Broad., 107 F.3d at 1336; Players Int'l, 988 F. Supp. at 506. In Greater New Orleans Broadcasting Ass'n v. United States, 149 F.3d 334, 338 (5th Cir. 1998), cert. granted, 119 S. Ct. 863 (1999), however, the Fifth Circuit reached the opposite conclusion regarding broadcast advertising for legal casino gambling in Louisiana and Mississippi, holding that " $[\mathrm{t}]$ he government may legitimately distinguish among certain kinds of gambling for advertising purposes, determining that the social impact of activities such as state-run lotteries, Indian and charitable gambling include social benefits as well as costs and that these other activities often have 
statute, although targeted at the novel threat posed by the new technology of broadcasting, incorporated prior terminology by condemning any advertising for a "lottery" or "similar scheme." 46 The Supreme Court, however, has held that these historical concepts are broad enough to cover any game of chance played for consideration, ${ }^{47}$ a definition that has been held to encompass casino and other modern forms of commercial gambling. ${ }^{43}$

Another illustration of Congress's efforts to protect, state choices while keeping pace with technological changes was its response to the proliferation of state-sanctioned lotteries. ${ }^{49}$ Through the 1980 s, individuals in non-lottery jurisdictions wishing to play lotteries run by other states would arrange for agents in those states to purchase lottery tickets for them and illegally ship them back. ${ }^{50}$ In the 1990 s, however, new communications technologies made the physical shipping of tickets unnecessary. One company, Pic-A-State, began accepting lottery picks for out-of-state lottery tickets on behalf of its customers, giving them only a computer-generated receipt. ${ }^{51}$ Tickets were purchased by Pic-A-State's employees in a lotterylawful state, but any payouts were based on Pic-A-State's computer records in the customer's jurisdiction. This avoided the necessity of transporting actual lottery tickets across state lines, nicely sidestepping the transportation prohibition of 18 U.S.C. $\S 1301 .^{52}$

In response to this technological loophole, Congress amended $\S 1301$ in the Interstate Wagering Amendment. ${ }^{53}$ The statute now outlaws, in addition to the physical trafficking of lottery tickets in interstate commerce, any business, engaged in selling chances to win "in a lottery, gift, enterprise or similar scheme" conducted by a State, that "knowingly transmit[s] in

dramatically different geographic scope." The circuit split will likely be resolved by the Supreme Court when it decides Greater New Orleans Broadcasting Ass'n.

46. Pub. L. No. 416 , ch. $652, \S 316,48$ Stat. at 1088.

47. See FCC v. ABC, 347 U.S. 284, 290 (1954) (stating that 18 U.S.C. $\$ 1304$ prohibits any form of gambling where prizes are awarded, according to chance, for consideration). The Court, however, rejected the FCC's argument that radio and television quiz shows that gave away prizes to contestants at home fell within this broad definition, holding that tuning into these programs did not constitute consideration. See id. at 294.

48. See, e.g., Greater New Orleans Broad. Ass'n v. United States, 69 F.3d 1296, 1298-99 (5th Cir. 1995) (holding that $\$ 1304$ prohibits advertising for casino gambling), cert. granted, $119 \mathrm{~S}$. Ct. 863 (1999); Players Int'l v. United States, 988 F. Supp. 497, 506 (D.N.J. 1997) (holding that broadcasts for casino gaming fall within the prohibition of $\$ 1304$ ).

49. See supra note 30 and accompanying text.

50. See, e.g., United States v. Steubben, 799 F.2d 225 (5th Cir. 1986) (affirming the conviction of the operator of a company engaged in this business under, inter alia, 18 U.S.C. $\$ 1301)$.

51. See Pic-A-State Pa., Inc. v. Reno, 76 F.3d 1294, 1297 (3d Cir. 1996).

52. See id.

53. See Violent Crime Control and Law Enforcement Act of $1994 \$$ 320,905, Pub. L. No. 103222, 108 Stat. 1796, 2126 (amending 18 U.S.C. $\S 1301$ ). 
interstate or foreign commerce information to be used to procure such a chance." 54

The Interstate Wagering Amendment was not the first time Congress elected to supplement individual states' approaches to gambling by outlawing interstate transmissions of "information" pertaining to gambling. ${ }^{55}$ It previously did so in the Wire Wager Act ${ }^{56}$ one of several anti-racketeering laws passed in the 1960 s to combat organized crime. ${ }^{57}$ It is the breadth of the Wire Wager Act that has attracted the most attention in the Internet gambling context because, notwithstanding the potential applicability of other federal laws, ${ }^{58}$ it directly prohibits the use of a wire transmission facility to foster a gambling business. It provides, in relevant part:

Whoever being engaged in the business of betting or wagering knowingly uses a wire communication facility for the transmission in interstate or foreign commerce of bets or wagers or information assisting in the placing of bets or wagers on any sporting event or contest, or for the transmission of a wire communication which entitles the recipient to receive money or credit as a result of bets or wagers, or for information assisting in the placing of bets or

54. Id.; see also Pic-A-State Pa., 76 F.3d at 1297 (noting the amendment of $\$ 1301$ from penalizing one who "carries" lottery tickets to one who "transmits" such tickets).

55. See Pic-A-State Pa., 76 F.3d at 1302; see also Valley Broad. v. United States, 107 F.3d 1328,1335 (9th Cir. 1997) (striking down on First Amendment grounds $\$ 1304$ 's ban on broadcast advertising of casino gambling, despite the government's asserted interest " 'to assist states that prohibit casino gambling... by regulating interstate activities such as broadcasting that are beyond the powers of individual states to regulate"'), cert. denied, $118 \mathrm{~S}$. Ct. 1050 (1998).

56. 18 U.S.C. $\$ 1084$ (1994). Section 1084 serves the twin purposes of assisting states in their respective approaches to gambling and suppressing gambling overall. See United States v. McDonough, 835 F.2d 1103, 1104-05 (5th Cir. 1988) (explaining that the dual purposes of $\$ 1084$ are to assist state law enforcement " and to aid in the suppression of organized gambling activities"' (quoting H.R. REP. No. 967 (1961), reprinted in 1961 U.S.C.C.A.N. 2631, 2633)).

57. Its companion laws were the Travel Act, 18 U.S.C. $\S 1952$ (1994), which outlawed "travel[] in interstate or foreign commerce or [use] ... [of] the mail" in furtherance of "unlawful activity," including "any business enterprise involving gambling"; the Interstate Transportation of Wagering Paraphernalia Act ("ITWPA"), 18 U.S.C. \$ 1953 (1994), which rendered unlawful the introduction into interstate commerce of "any record, paraphernalia, ticket, certificate, bills, slip, token, paper, writing or other device used, or to be used" in gambling; and 18 U.S.C. $\$ 1955$ (1994), which prohibited owning or operating an illegal gambling business, which is defined as a gambling business that violates state law, involves five or more persons and either is in substantially continuous operation for more than 30 days or has a gross revenue of more than $\$ 2000$ in any single day.

58. Internet gambling sites, as currently operated, appear to violate several of the provisions of these acts. For instance, the allegations in the Southern District of New York prosecutions recount the use of the mails and telephone to provide information and set up accounts for gamblers, in violation of 18 U.S.C. \$ 1952. See infra notes 108-113, 172-174, 196-209 and accompanying text. Similarly, operations involving five or more persons violate $\S 1955$, and the shipping, via interstate commerce, of the hardware and software needed to run the offshore computers may violate $\S 1953$. 
wagers, shall be fined under this title or imprisoned not more than two years, or both. ${ }^{59}$

This language, on its face, is broad enough to cover Internet gambling, which, given today's technology, necessarily involves the use of a "wire communication facility" ${ }^{60}$ for "the transmission" of "bets or wagers" or information that assists the "placing of bets or wagers."

Particularly significant for the application of §1084(a) to Internet gambling is that it does not simply outlaw the placing or taking of bets or wagers, as, for example, many state laws do. Instead, it focuses on the knowing "use" of a wire communication facility in connection with a gambling business. ${ }^{61}$ Properly analyzed, this should marginalize disputes over whether a transmission in violation of the Act requires the placing or receiving of bets. The Act underscores this point by prohibiting not only the act of gambling, but also transmissions of any information that make it possible to bet in the first place.

Furthermore, $\S 1084$ prohibits the interstate transmission of bets or gambling information irrespective of whether the ultimate bet violates the law of the state where the gambling takes place. This contrasts, for instance, with $\S 1955$, which criminalizes gambling businesses only to the extent that they violate state law. $^{62}$ Similarly, $\S 1084$ prevents the interstate transmission of information that would assist gambling, such as the transmission of basketball results from Indiana to Nevada, other than in the context of news reporting. Section 1084(b) also allows the transmission-of information only, not bets-from a state where betting on the event is legal to another state where such betting is also legal. ${ }^{63}$ The House Report on $\S 1084$ emphasizes that "[n]othing in the exemption, however, will permit the transmission of bets and wagers or money by wire as a result of a bet or

59. 18 U.S.C. $\$ 1084(a)$ (1994).

60. A "wire communication facility" is broadly defined in 18 U.S.C. $\S 1081$ as any form of instrumentality or service "used or useful in the transmissions of writings, signs, pictures and sounds of all kinds by aid of wire, cable or other like connection." As the legislative history to $\$ 1084$ makes clear, Congress adopted a broad definition of "wire communication facility" in part because of the recognition that "[m]odern bookmaking depends in large measure on the rapid transmission of gambling information." H.R. REP. No. 87-967, at 2 (1961), reprinted in 1961 U.S.C.C.A.N. 2631, 2631-32.

61. See Sagansky v. United States, 358 F.2d 195, 200 (1st Cir. 1966) ("[Section] 1084(a) does not punish the mere transmission of bets or wagers, but rather the 'use' of interstate wire communication facilities for their transmission.").

62. See supra note 57.

63. 18 U.S.C. \$ 1084(b) ("Nothing in this section shall be construed to prevent the transmission ... of information for use in news reporting ... or for the transmission of information assisting in the placing of bets or wagers on a sporting event or contest from a State or foreign country where betting on that sporting event or contest is legal into a State or foreign country in which such betting is legal."); see also Telephone News Sys. v. Illinois Bell Tel. Co., 220 F. Supp. 621,627 (N.D. Ill. 1963) (finding that $\$ 1084$ (b) only exempts "certain types of transmissionsthose of information for use in news reporting and those sent from a state where the betting is legal to another state where betting is legal"). 
wager from or to any State whether betting is legal in that state or not." ${ }^{64}$ Therefore, in the online gambling context, the literal language of $\$ 1084$ condemns all Internet transmissions to the United States of the digitized bits of information that create the virtual gambling site on a user's computer screen. ${ }^{65}$

Two interpretation issues, however, do exist. First, the words "wire communication facility" arguably could fail to cover wireless transmissions. At present, however, there are no entirely wireless ways to use the Internet. ${ }^{66}$ Second, the specific prohibition in $\$ 1084$ on the transmission of "information assisting in the placing of bets or wagers on any sporting

64. H.R. REP. No. 87-967, at 3 (1961). As the report continues:

[p]hrased differently, the transmission of gambling information on a horserace from a State where betting on that horserace is legal to a state where betting on the same horserace is legal is not within the prohibitions of the bill. Since Nevada is the only Id.

State which has legalized offtrack betting, this exemption will only be applicable to it.

65. The question of whether an unlawful transmission has occurred has, in other contexts, led courts to focus on whether bets were placed or received. See United States v. Tomeo, 459 F.2d 445 (10th Cir. 1972) (summarizing cases reflecting a split in authority); United States v. Reeder, 614 F.2d 1179, 1184 (8th Cir. 1980) (concluding that the "prevailing view" is that $\$ 1084(a)$ covers the use of wire communications facilities by those in the gambling business, whether sending, receiving, or both is involved). To avoid the application of $\$ 1084(a)$, an offshore cybercasino would have to argue that its server does not use the Internet to transmit anything at all, an argument that is contrary to common sense and established case law. In Minnesota v. Granite Gate Resorts, No. C6-95-7227, 1996 WL 767431 (Minn. Dist. Ct. Dec. 11, 1996), "the contention of Defendants [was] that WagerNet has transmitted nothing over the Internet and that the only person in this case who would transmit anything would be Minnesota residents who contact Wager Net." Id. at *8. The court properly found this proposition absurd:

[W] hen the Minnesota user plugs in the URL address for Vegas.Com, if Vegas.Com did not send an electronic transmission back to the computer user, the computer user would see nothing. He or she would see a blank screen. The way that the pictures and words get to the Minnesota residents is by the server, Vegas.com, automatically transmitting it back to the Minnesota resident.... [O]ne who sets up his or her system and knows that anyone accessing his or her site will get that information, then the server ought to be held responsible for that information.

Id. (citing Playboy Enters. v. Chuckleberry Publ'g Co., 939 F. Supp. 1032, 1044 (S.D.N.Y. 1996)); see also United States v. Kammersell, 7 F. Supp. 2d 1196, 1200 (D. Utah 1998) (holding that the "use of an Internet server by defendant" for an interstate message constituted a transmission).

66. Cf. Debra Baker, Betting on Cyberspace, A.B.A. J., Mar. 1999, at 54, 56 ("Although many computer modems run over telephone wires, the complexities of Internet transmissions, as well as satellite technology, make it unclear whether all Internet communications will fall within the scope of the [Kyl Bill]."). Although connections to the Internet may be made wirelessly, connections within the Internet still depend on wires, making it a "wire communication facility." See PRESTON GRALLA, How THE INTERNET WORKS 5-7 (4th ed. 1998) ("[L]ines that connect networks can be as simple as a single telephone line or as complex as a fiber-optic cable with microwave links and satellite transmissions.").

Moreover, the legislative history of the Act makes clear that Congress intended to exclude wireless communication only for fear of treading on the rights of broadcasters. The only kinds of wireless communication specifically excluded are radio and television broadcasts:

There is nothing in this bill which would in any way affect the press, radio or TV in its reporting of sporting events. In fact, wireless communication was not included in this bill because it is our belief that the Federal Communications Commission has ample authority to control the misuse of this means of communication.

S. REP. NO. 87-588, at 3 (1961). 
event or contest ${ }^{27}$ has led some to suggest that $\S 1084$ covers bets or wagers only on events or contests that involve sports. Given that the Act also prohibits, without modification, "the transmission in interstate or foreign commerce of bets or wagers" 68 and "information assisting in the placing of bets or wagers," ${ }^{69}$ this would seem to be a strained interpretation. Additionally, the House and Senate Reports on the Act consistently refer generally to "bets and wagers" without limiting them to sports bets. ${ }^{70}$ The singling-out of information relating to "any sporting event or contest" reflects the popularity, at the time the Act was passed, of sports betting via telephone. ${ }^{71}$ There also have been, however, several indictments under the Act for numbers games carried on by telephone. ${ }^{72}$ To conclude that $\S 1084$ is limited to sports betting, one has to accept the argument that Congress intended to carve the numbers racket out from its reach. This would be an unlikely conclusion, given the nexus between that form of gambling and organized crime. ${ }^{73}$

In light of this, the Kyl bill, ${ }^{74}$ which was introduced in the 105th Congress to regulate Internet gambling, is, at least in part, superfluous. One of its purposes was to clarify that the Wire Wager Act covers all forms of telecommunications used to transmit all types of gambling information, including, but not limited to, information about sporting events. Another purpose was to denominate "the Internet or any other interactive computer service" as included within the channels of communication in which gambling is forbidden. ${ }^{75}$ Such clarification seems unnecessary in light of $\S$

67. 18 U.S.C. § 1084(a) (1994) (emphasis added).

68. Id. (emphasis added).

69. Id. (emphasis added).

70. See, e.g., H.R. REP. No. 87-967, at 2-4 (1961); S. REP. No. 87-588, at 2-5 (1961).

71. See United States v. Segal, 867 F.2d 1173, 1175 (8th Cir. 1989); United States v. Stonehouse, 452 F.2d 455, 456 (7th Cir. 1971); Telephone News Sys. v. Illinois Bell Tel., 220 F. Supp. 621,624 (N.D. Ill. 1963); see also PILEGGI, supra note 1, at 67 ("Robert Kennedy had pushed a bill through Congress prohibiting the interstate transmission of any gambling information, making Lefty's phone calls about team injuries, lineups, odds, and even weather conditions against the law and subjecting him to arrest.").

72. See, e.g., United States v. Chase, 372 F.2d 453, 457 (4th Cir. 1967); United States v. Giovanelli, 747 F. Supp. 897, 902 (S.D.N.Y. 1989); United States v. Manetti, 323 F. Supp. 683, 687 (D. Del. 1971). Moreover, although there is no reported decision on point, the Justice Department and several state attorneys general have taken the position that "sporting" does not modify "contest" and that casino-type gaming is a "contest" also prohibited under the Act. See 2 CABOT, supra note 4, at 115 \& n.117 ("[T]he Justice Department holds the position that gambling on the Internet is illegal under Section 1084."); id. at 114 n.111 (citing a private letter ruling by the Texas Attorney General, Tex. Priv. Ltr. Rul. DM-344 (May 2, 1995), that Internet card games violate § 1084); see also INTERNET TASK FORCE, INTERNET GAMBLING STAFF SUBCOMM., NATIONAL ASS'N OF ATTORNEYS GEN., GAMBLING ON THE INTERNET 17-18 (1996) (discussing the application of Wire Wager Act beyond sports).

73. When, in 1893, the last State lottery was forced out of business in the United States, lotteries were replaced in popularity with the numbers racket, which remained a lucrative business for organized crime until state-authorized lotteries began to reappear in the mid-1960s. See O'BRIEN, supra note 3, at 158-63.

74. S. 474, 105th Cong. (1997).

75. H.R. 4276, 105th Cong. (1998). As the House version of the bill provides: 
1084's plain language prohibiting the use of a "wire communication facility," which the Internet clearly is.

\section{Challenges to Federal AuthortTy To CRIMINALIZE Gambling}

The broad language of $\$ 1084$ seems tailor-made for application to Internet gambling. Enacted in $1961,{ }^{76}$ however, it plainly was not drafted with Internet gambling in mind. Yet, most of the likely constitutional challenges that could be raised in the Internet context already have been argued in the context of other wire communications facilities and uniformly have been rejected. In fact, virtually all of Congress's efforts to supplement and reinforce individual state approaches to gambling already have been upheld against First Amendment, ${ }^{77}$ vagueness, ${ }^{78}$ and Commerce Clause challenges. ${ }^{79}$

The Supreme Court recently reviewed the history of congressional antigambling legislation and challenges to it in United States v. Edge Broadcasting. ${ }^{80}$ The statute at issue in Edge was 18 U.S.C. $\S 1304$, which prohibits radio and television stations from broadcasting lottery advertising unless they are licensed in the state that runs the lottery being advertised. ${ }^{81}$ It did not, therefore, involve facts that bear directly on the issue of Internet gambling. Edge nevertheless set the stage for the conclusion that 18 U.S.C. $\S 1084$ is lawfully applied to Internet gambling prosecutions in at least two ways. First, the Court began its analysis by emphasizing the breadth of congressional authority under the Commerce Clause, ${ }^{82}$ using as an example the Louisiana Lottery, with which Congress seemed particularly concerned in the $1890 \mathrm{~s} .{ }^{83}$ It noted that when the Louisiana Lottery moved its operations

[I] $t$ shall be unlawful for a person knowingly to use the Internet or any other interactive computer service... to place, receive, or otherwise make a bet or wager with any person; or ... to send, receive, or invite information assisting in the placing of a bet or wager with the intent to send, receive, or invite information assisting in the placing of a Id. bet or wager.

76. See Pub. L. No. 87-216, § 2, 75 Stat. 491 (1961).

77. For example, the 1876 statute prohibiting the use of the mails to promote both illegal and state-authorized lotteries was challenged unsuccessfully on First Amendment grounds. See Ex parte Jackson, 96 U.S. 727 (1877) (upholding the Act of July 12, 1876, 19 Stat. 90). When lotteries resorted to advertising in newspapers and Congress reacted by outlawing the mailing of newspapers carrying such advertisements, that Act also was challenged and upheld. See In re Rapier, 143 U.S. 110 (1892) (upholding the Anti-Lottery Act of 1890, ch. 908, § 1, 26 Stat. 465).

78. See, e.g., United States v. Borgese, 235 F. Supp. 286, $295-97$ (S.D.N.Y. 1964); United States v. Smith, 209 F. Supp. 907,918 (E.D. IIl. 1962).

79. See infra notes $80-90$ and accompanying text.

80. 509 U.S. 418 (1993).

81. See id. at 422.

82. See id.

83. See id. at 421 . This remarkably persistent lottery-apparently the last of the state lotteries until New Hampshire revived its system in the 1960s-was chartered by the Louisiana legislature on August 11, 1868, and given a monopoly on sales of lottery tickets within that state, partly in 
to Latin America, Congress responded by " outlaw[ing] the transportation of lottery tickets in interstate or foreign commerce. This Court upheld the constitutionality of that Act against a claim that it exceeded Congress's power under the Commerce Clause.... This federal antilottery legislation remains in effect." 84

The case to which the Court referred was Champion v. Ames, commonly called the Lottery Case. ${ }^{85}$ Champion was accused of conspiring to transport lottery tickets between Texas and California for the Louisiana Lottery's then most recent incarnation, the "Pan American Lottery Company," an offshore gambling operation with monthly drawings held at Ascuncion, Paraguay. ${ }^{86}$ Because, according to Edge, the Lottery Case remains good law, ${ }^{87}$ the Supreme Court has already upheld the validity of a federal gambling prosecution based, at least in part, on a gambling operation outside of the United States, in a jurisdiction that has legalized gambling. This has obvious significance in the Internet context.

Second, by citing with approval to the Lottery Case, the Edge Court leads one back to Pensacola Telegraph $v$. Western Union Telegraph, ${ }^{88}$ on which the Lottery Case relied extensively. Pensacola held unconstitutional Florida's attempt to grant a local company a monopoly over the Internet's turn-of-the-century equivalent: the telegraph. Quoting extensively from the Pensacola Court's opinion, the Lottery Case decision emphasized that Commerce Clause powers " are not confined to the instrumentalities of commerce... known or in use when the Constitution was adopted, but ... keep pace with the progress of the country, and adapt themselves to the new developments of time and circumstances." 89

self-defense, because "many millions of dollars have been withdrawn from and lost to this State by the sale of Havana, Kentucky, and Madrid and other lottery tickets, thereby impoverishing our own people." Spofford, supra note 29, at 190 (quoting an anonymous source). In return, the Lottery paid $\$ 40,000$ per year to the state treasury out of profits that approached one million dollars annually. When, in 1879 , the legislature repealed its grant, the Lottery successfully lobbied a state constitutional convention for reinstatement. In 1890, faced again with extinction, the Lottery promised the legislature $\$ 1.25$ million annually for a 25 -year franchise extension. This proposal was vetoed by the governor. See id. at 190-92. After long judicial proceedings, the Lottery moved to Honduras, leading Congress, in 1895, to add "foreign" to the type of commerce in which lottery ticket trafficking was illegal. See Edge Broad., 509 U.S. at 422 . The Louisiana Lottery's unsavory character, its ubiquity, and its resistance to attempts to kill it earned it the nickname "Serpent" and condemnation as "this hydra-headed monster, which is demoralizing the young, the poor, and the needy throughout the country, as no institution in America has ever done." G. Robert Blakey \& Harold A. Kurland, The Development of the Federal Law of Gambling, 63 CORNELL L. REv. 923, 937-39 (1978) (quoting Rep. Moore); see also O'BRIEN, supra note 3, at 106-08 (tracing the Louisiana Lottery to its ultimate demise in Honduras in 1907).

84. Edge Broad., 509 U.S. at 422.

85. 188 U.S. 321 (1903).

86. See id. at 323. In fact, it appears the tickets in dispute were printed in the United States. See id. at 364 (Fuller, J., dissenting).

87. See Edge Broad., 509 U.S. at 422.

88. 96 U.S. 1 (1877).

89. Lottery Case, 188 U.S. at 350 (quoting Pensacola Tel., 96 U.S. at 9). 
Then, in words directly applicable to the Internet, the Court focused on the commercial importance of the telegraph, describing it as " an epoch in the progress of time. In a little more than a quarter of a century it has changed the habits of business and, become one of the necessities of commerce. It is indispensable as a means of intercommunication, but especially is it so in commercial transactions." "90 The Pensacola approach to Commerce Clause authority makes it abundantly clear that Internet communications in the late twentieth century, including those with foreign implications, should be within the scope of the Commerce Clause.

More recent challenges to federal gambling legislation have arisen in the context of criminal prosecutions under 18 U.S.C. $\$ 1084$, as well as its companion legislation from the 1960s. Two such $\S 1084$ prosecutions, in particular, shed light on the applicability of $\$ 1084$ to online gambling.

In Martin v. United States, ${ }^{91}$ the appellants were convicted for transmitting bets and betting information about football games by telephone from Houston to Las Vegas. ${ }^{92}$ They challenged the constitutionality of $\S 1084$ on the theory that their conviction for transmitting wagers to Las Vegas, where those bets were legal, resulted in an unconstitutional application of the statute "to defeat the policies of Nevada." 93 The Fifth Circuit rejected that defense, noting that Congress's power under the Commerce Clause to prohibit such communications was sufficiently broad to cover communications between states taking different approaches to gambling. The court, therefore, concluded that the interstate transmission of wagers could be proscribed whether or not betting is lawful in the state where the bet is received. ${ }^{94}$

United States $v$. Blair $^{95}$ also is instructive. Blair illustrates that 18 U.S.C. $\S 1084$ can be used to prosecute not only communications between different states, but also between the United States and offshore, gamblinglegal jurisdictions. Blair was convicted of violating $\S 1084$ by accepting "wagers on professional and college basketball games from residents" of Oklahoma "over the phone via a toll-free number he had established" while he was located in the Dominican Republic. ${ }^{96}$ Having entered a guilty plea, Blair argued on appeal that the district court should not have accepted the

90. Id. at 351 (quoting Pensacola Tel., 96 U.S. at 9).

91. 389 F.2d 895 (5th Cir. 1968).

92. See id. at 896.

93. Id. at 897; see also Rory K. Little, Myths and Principles of Federalization, 46 HASTINGS L.J. 1029, 1062 n.154 (1995) (citing the Lottery Case, 188 U.S. 321, 357-58 (1903), for the proposition that "the Supreme Court long ago rejected Tenth Amendment arguments as a bar to assertion of federal criminal jurisdiction").

94. See Martin, 389 F.2d at 899-900; see also United States v. McDonough, 835 F.2d 1103 (5th Cir. 1988) (finding transmissions of bets from Texas to Massachusetts to be unlawful, regardless of whether they violated Massachusetts law); Cohen v. United States, 378 F.2d 751 (9th Cir. 1967) (finding that transmissions from Las Vegas to California were illegal).

95. 54 F.3d 639 (10th Cir. 1995).

96. Id. at 641 . 
plea because no factual basis existed to establish he acted with knowledge that federal law prohibited his offshore communications. ${ }^{97}$ The Tenth Circuit disagreed, holding that it was sufficient for the government to have established Blair's knowing and willful establishment of "a bookmaking operation in the Dominican Republic." 98

Although none of the challenges to $\S 1084$ have been decided by the Supreme Court, the Justices have reviewed related legislation and concluded that, absent a specific exemption for gambling activities authorized by state or foreign governments, federal antigambling statutes criminalize U.S.based participation in such activities. For example, in United States $v$. Fabrizio, ${ }^{99}$ the Court emphasized that at the time $\S 1084$ and its companion antigambling legislation were enacted, Congress was well "aware of legal sweepstakes run by governments in other countries," ${ }^{100}$ yet declined to enact sweeping exemptions for such activities. Instead, it explained, Congress took a more narrow approach, creating exemptions where it thought appropriate. Given the absence of any such exemption in the statute Fabrizio was accused of violating, ${ }^{101}$ the Court concluded that even lawful state or foreign-based gambling operations properly were included within the scope of federal prohibitions. ${ }^{102}$

The preceding line of authority undermines any argument that the Internet is so new and unique as to fall beyond the scope of Congress's authority to criminalize its use for certain acts. The issue of technological uniqueness, as Pensacola shows, never has been an impediment to congressional action. The only issue is whether the Internet is capable of being used as an instrumentality of commerce ${ }^{103}$ to further gambling activities, which plainly it is. ${ }^{104}$

\section{See id. at $641-42$.}

98. Id. at 644 .

99. 385 U.S. 263 (1966).

100. Id. at 268. The Court specifically noted legislative history offering the Irish Sweepstakes as an example of a lawful, offshore gambling operation that nonetheless could trigger liability. Id. at 268 n.5. Fabrizio was indicted for purchasing tickets to the 1964 New Hampshire Sweepstakes, which was the first legal lottery in the United States. See O'BRIEN, supra note 3, at 164.

101. Fabrizio had allegedly violated the Interstate Transportation of Wagering Paraphenalia Act ("ITWPA"), 18 U.S.C. $\$ 1053$ (1994), when he traveled to New Hampshire to purchase- on behalf of others-75 tickets to the New Hampshire Sweepstakes and retumed to Elmira, New York with receipts acknowledging the purchases. See Fabrizio, 385 U.S. at 271, 274 n.3.

102. See Fabrizio, 385 U.S. at 269.

103. The Internet already has been recognized as an instrumentality of commerce for the purposes of criminal law. See United States v. Kammersell, 7 F. Supp. 2d 1196, 1200 (D. Utah 1998).

104. Nor is it persuasive to make the Internet-gambling specific argument that the lawful reach of federal antigambling statutes cannot govern communications that encompass one jurisdiction where gambling is legal. It does not appear that such a defense was asserted even in United States v. Truesdale, 152 F.3d 443 (5th Cir. 1998), where the defendants otherwise obtained reversal of their convictions for operating a bookmaking operation in the Dominican Republic, Jamaica, and Dallas, Texas. Truesdale is interesting because the evidence clearly showed substantial use of toll-free telephone numbers to provide betting information and accept bets. See $i d$. at 444. It also showed that the head of the gambling operation lived in Dallas, but monitored his 


\section{THE RECENT APPLICATION OF § 1084 TO INTERNET GAMBLING}

Internet gambling operators have not been bashful about promoting themselves as a purportedly legal way to circumvent traditional gambling restrictions. Those claims, however, clash with the broad reach of the federal antigambling authority and the number of times such legislation has withstood constitutional challenge. It was not surprising, therefore, that in the spring of 1998, the United States Attorney for the Southern District of New York announced the filing of criminal complaints against twenty-one offshore Internet-gambling operators under the Wire Wager Act. These prosecutions are the federal government's first effort to attack the proliferation of online gambling. ${ }^{105}$

The complaints alleged that these offshore sports gambling sites, with names such as "Real Casino," "Galaxy Sports," and "Winner's Way," 106 had advertised in sports and airline in-flight magazines touting the ease and convenience of betting via the Internet and listing their Web site addresses. ${ }^{107}$ Interestingly, although all the Web sites purportedly were operated in the Caribbean or Costa Rica under licenses issued by the host

Caribbean operations through various means, including obtaining betting information via computer. See id. at 445 . For whatever reason, however, the prosecution did not rely on 18 U.S.C. $\S 1084$ as the foundation for a substantive charge. Instead, the defendants were indicted for conducting an illegal gambling business in violation of 18 U.S.C. $\S 1955$. This statute requires proof that the operation violates the law of the state in which it is conducted. See Truesdale, 152 F.3d at 447. The government's case, however, contained no direct proof that any bets were accepted in Texas. See id. at 447. The Fifth Circuit ruled that it was "irrational to conclude beyond a reasonable doubt that after having gone through the effort of fully equipping, staffing, and widely advertising the Caribbean offices, the appellant nevertheless illegally accepted bets" in Texas. Id. at 448 . Without proof of this predicate offense, all of the remaining convictions were also reversed.

105. See infra note 229 and accompanying text.

106. United States Attorney, Southern District of New York, Press Release (visited Mar. 10, 1998) <http://www.rgtonline.com/newpage/artlisting.cfm/2092>; see Sealed Complaint II 8, United States v. Budin, No. 98-m-00463 (S.D.N.Y. Mar. 2, 1998) ("www.sdbg.com"); Sealed Complaint II 8, United States v. B. Cohen, No. 98-m-00462 (S.D.N.Y. Mar. 2, 1998) ("www.realcasino.com"); Sealed Complaint II 8, United States v. J. Cohen, No. 98-m-00465 (S.D.N.Y. Mar. 2, 1998) ("www.wsex.com"); Sealed Complaint I 8, United States v. Hunter, No. 98-m-00464 (S.D.N.Y. Mar. 2, 1998) ("www.galaxysports.com"); Sealed Complaint II 8, United States v. Rogers, No. 98-m-00466 (S.D.N.Y. Mar. 2, 1998) ("www.winnersway.com"); Sealed Complaint II 8, United States v. Ross, No. $98-m-00467$ (S.D.N.Y. Mar. 2, 1998) ("www.islandcasino.com").

107. For example, an advertisement for SDB Global appeared in College and Pro Football Newsweekly and Pro Football Weekly stating, "Bet any sport ... Anytime... Anywhere" and offering “' [m]embers only' internet access for up-to-the-minute scores/time changes." Sealed Complaint $\mathbb{T}$ 29, United States v. Budin, No. 98-m-00463 (S.D.N.Y. Mar. 2, 1998) ("www.sdbg. com"). An advertisement in Pro Football Weekly for another Web site praised football betting online as a "good use for the Internet." Sealed Complaint II 24, United States v. J. Cohen, No. 98-m00465 (S.D.N.Y. Mar. 2, 1998) ("www.wsex.com"). An advertisement in Continental Airlines's in-flight magazine announced, "[s]portswagering [is] now available on the Internet .... Winner's Way gives you wagering freedom at your fingertips-and it doesn't get any safer, easier or more secure." Sealed Complaint II 23, United States v. Rogers, No. 98-m-00466 (S.D.N.Y. Mar. 2, 1998) ("www.winnersway.com"). 
country, the complaints indicate that several entities run by the defendants had offices in the United States. ${ }^{108}$ Other United States contacts included toll-free telephone numbers over which undercover FBI agents received gambling information ${ }^{109}$ and could place bets, ${ }^{110}$ as well as wire transfers of money from the United States to offshore banks. ${ }^{111}$ Additionally, some of the sites used the U.S. mails to send informational brochures to American customers. ${ }^{112}$ There were further contacts via e-mail and wire transfers of refunds back to the United States. ${ }^{113}$ All of these communications are alleged to have violated the prohibitions of $\S 1084$.

In early March 1998, warrants were issued for the arrest of fourteen gambling operators, eleven of whom surrendered or were arrested. ${ }^{114} \mathrm{~A}$ few weeks later, warrants were issued for the arrest of seven additional gambling operators. ${ }^{115}$ All twenty-one were U.S. citizens. On April 9, 1998, Michael

108. See Sealed Complaint पII 9, 23, United States v. Budin, No. 98-m-00463 (S.D.N.Y. Mar. 2,1998 ) ("www.sdbg.com") (alleging that promotional literature was sent from the defendant's New York office); Sealed Complaint II 22(d), United States v. B. Cohen, No. 98-m-00462 (S.D.N.Y. Mar. 2, 1998) ("www.realcasino.com") (stating that the defendant's Colorado office was involved in marketing); Sealed Complaint $\mathbb{I}$ 16, United States v. Rogers, No. 98-m-00466 (S.D.N.Y. Mar. 2, 1998) ("www.winnersway.com") (alleging that the defendant maintained marketing offices in the U.S., including two offices in Las Vegas); Sealed Complaint 1 III 8, 9, 12, 13, United States v. Stofan, No. 98-m-00644 (S.D.N.Y. Mar. 2, 1998) ("199.95.251.71/gsn") (stating that an informational brochure was sent from the defendant's New Jersey office, where calls to a toll-free telephone number were answered). Where the servers were located is not clear from the complaints. See, e.g., Sealed Complaint I 31, United States v. Hunter, No. 98-m-00464 (S.D.N.Y. Mar. 2, 1998) ("www.galaxysports.com") (reporting that the defendant's Web site was registered to a company with a Dallas address). If proven, these contacts make even less persuasive any personal jurisdiction or due process arguments that might be raised. See infra notes 128-137 and accompanying text.

109. See Sealed Complaint II 7(b), United States v. Stofan, No. $98-m-00644$ (S.D.N.Y. Mar. 20 1998) (“199.95.251.71/gsn/).

110. See id. II 8.

111. To open accounts on the sports betting sites named in the Southern District of New York complaints, FBI agents transferred funds by wire to banks in the home countries of the gambling sites. See, e.g., Sealed Complaint II 11, United States v. B. Cohen, No. 98-m-00462 (S.D.N.Y. Mar. 2, 1998) ("www.realcasino.com") ("[T]he U[nder]C[over] sent $\$ 500$ by Western Union to meet the minimum deposit requirement of Real Casino. The Western Union transfer was made out to "Informacion Real."); id. II 24 ("[T]he originating bank of the wire transfer was Banco Continental in Panama."); Sealed Complaint II 12, United States v. Hunter, No. 98-m-00464 (S.D.N.Y. Mar. 2, 1998) ("www.galaxysports.com") ("[T]he U[nder]C[over] opened an account with Galaxy Sports by sending $\$ 600$ by Westem Union from New York, New York."); id. II 18 ("The check [for winnings] was written on an account of "Bank of Nevis Ltd.")).

112. See Sealed Complaint II 13, United States v. Stofan, No. 98-m-00644 (S.D.N.Y. Mar. 20 1998) (“' 199.95.251.71/gsn/").

113. See Sealed Complaint $\mathbb{I I I} 16,23$, United States v. B. Cohen, No. $98-\mathrm{m}-00462$ (S.D.N.Y. Mar. 2, 1998) ("www.realcasino.com").

114. United States Attomey, Southem District of New York, Press Release (visited Apr. 16, 1998) <http://www.rgtonline.com/newspage/artlisting.cfm?textID $=2153>$.

115. See Sealed Complaint, United States v. Lnu, No. 98-m-00675 (S.D.N.Y. Mar. 24, 1998) ("www.wsex.com"); Sealed Complaint, United States v. Moore, No. 98-m-00677 (S.D.N.Y. Mar. 24, 1998) ("www.galaxysports.com"); Sealed Complaint, United States v. Peters, No. 98-m00643 (S.D.N.Y. Mar. 20, 1998) ("www.ghconline.com"); Sealed Complaint, United States v. Stofan, No. 98-m-00644 (S.D.N.Y. Mar. 20 1998) ("199.95.251.71/gsn/"); Sealed Complaint, United States v. Scott, No. 98-m-00642 (S.D.N.Y. Mar. 20, 1998) ("www.wwrs.com"). 
Saul of Island Casino became the first person convicted of Internet gambling under the Act when he pled guilty to one count of conspiracy. By December 1998, six of the twenty-one arrested had pleaded guilty to various felonies and misdemeanors. ${ }^{116}$

\section{WHY SHOULDN'T INTERNET GAMBLING BE PROSECUTED?}

The weight of authority suggests that any defenses to these federal prosecutions predicated on the contention that gambling is legal in the jurisdiction where these operators place their servers ultimately should fail. ${ }^{17}$ There is no precedent to support the suggestion that U.S. residents are "making a virtual visit to Antigua," or that Commerce Clause power cannot proscribe the placing of bets between New York and Antigua. The question then arises whether there are other sound constitutional or policy reasons for not prosecuting Internet gambling operators, either under the Wire Wager Act or related prohibitions.

116. See Chauncey Hollingsworth, Loaded Dice? Odds Are Regulators Can't Stem Tide of Internet Gambling, CHI. TRIB., Dec. 4, 1998, at 1. One of those arrested, Jay Cohen, unsuccessfully sought to dismiss the indictment based on a four-step argument. First, he claimed that no "betting" took place in the United States because all funds used to bet came out of a customer's pre-established account in Antigua. See Transcript of Oral Argument at 5, United States v. J. Cohen, No. 98 Cr. 434 (S.D.N.Y. Feb. 25, 1999). Second, he argued, because the money was already in Antigua, the only thing being transmitted to Antigua via the Internet is "either the placing of a bet or the transmission of information" assisting in the placing of bets. Id. at 7. Third, he argued that the "placing of bets" is not illegal in New York, from which the undercover agents made their online bets. Id. at 6 . As support for this proposition, he cited a New York case that criminalizes every aspect of gambling except the placing of the bets itself. See People v. Giordano, 663 N.E.2d 588, 591 (N.Y. 1995) ("Under the statutory scheme a mere 'player' or bettor is not criminally liable but one who, in some capacity other than as a player, participates in any gambling enterprise or activity is guilty of a crime."). Finally, he maintained that, because "placing a bet" is legal in New York, he could not be prosecuted for violating $\S$ 1084 because of the exception in $\S 1084(\mathrm{~b})$ that permits "the transmission of information assisting in the placing of bets or wagers on a sporting event or contest from a State or foreign country where betting on that sporting event or contest is legal into a State or foreign country in which such betting is legal." See Transcript of Oral Argument, supra, at 6-8.

Cohen's argument depends, at its core, on the underlying premise that by accessing remote Web sites, U.S. citizens make "virtual voyages" from their home states to transact business solely in the jurisdiction where the Web site server is located. As noted, this theory already has been rejected in other contexts. See, e.g., Playboy Enters. v. Chuckleberry Publ'g, 939 F. Supp. 1032, 1039 (S.D.N.Y. 1996) (rejecting the premise that, by accessing a Web server located in Italy, the U.S. user "transport[s] himself to Italy"). Moreover, Cohen's argument misses the point. Regardless of whether the fractional act of "placing a bet" is legal in New York for the person placing the bet, which it does not appear to be, see N.Y. GEN. OBLIG. LAW \$ 5-401 (McKinney 1989) (declaring "all wagers, bets or stakes ... unlawful"), the "betting" transaction clearly is illegal, as it necessarily involves more people than just the bettor, see Giordano, 663 N.E.2d at 591. Because $\$ 1084(\mathrm{~b})$ exempts only the transmission of betting information between states where the complete transaction of betting on sports events or contests is legal, and because such betting is not legal in New York, "information assisting in the placing of bets or wagers" that emanates from New York does not qualify for the exception under $\$ 1084(\mathrm{~b})$. On February 5, 1999, Chief Judge Thomas P. Griesa denied Cohen's motion to dismiss. See Transcript of Oral Argument, supra, at 57.

117. See supra notes $91-102$ and accompanying text. 


\section{A. The Societal Concerns Are Greater Online}

The societal concerns ${ }^{118}$ that have led to the heavy regulation of brickand-mortar casinos and other forms of gambling do not evaporate online. In fact, because there is no strict governmental oversight of online gambling machinery and accounting procedures, the prospects for dishonest operations increase. Moreover, the anonymity of Internet gambling makes it easier to indulge in excessive gambling. ${ }^{119}$

States that allow traditional casinos protect against these problems in a number of different ways:

- State gaming commissions require registration and licensing of all gambling operations. ${ }^{120}$

- Inspections of all gambling machinery and gaming tables ensure the safety and honesty of the games themselves. ${ }^{121}$

- Rigorous accounting standards and thorough inspections of account books ensure proper payouts, honest tax compliance, and minimal bribery and corruption. ${ }^{122}$

- To curb gambling impulses, many states restrict how and where gambling operations can be advertised, ${ }^{123}$ and federal law forbids lottery ads from being broadcast in states where lotteries are illegal. ${ }^{124}$

- Many states forbid gambling on credit. ${ }^{125}$

- States allow casinos to forbid gambling by drunks, ${ }^{126}$ minors, ${ }^{127}$ and other problem gamblers. ${ }^{128}$

118. See Kyl Bill Hearing, supra note 5, at 3 (statement of Chairman Jon Kyl) ("Society has always prohibited most forms of gambling because it can have a devastating effect on people and families, and it leads to other crime and corruption if not strictly regulated.").

119. Gambling addiction also leads to absenteeism, Internet gambling at work, and a consequent loss of productivity among people who are potentially the most productive in the work force. See id. at 19 (statement of Ann Geer, Chair, National Coalition Against Gambling Expansion).

120. See, e.g., LA. REv. STAT. ANN. § 27:240 (West Supp. 1999).

121. See, e.g., N.J. STAT. ANN. \& 5:12-79 (West 1996).

122. See, e.g., MiCH. COMP. LAWS $\$ 432.205(l)(4)$ (Supp. 1998); see also Kyl Bill Hearing, supra note 5, at 5 (statement of Sen. Bryan) (" [S]ince many of these sites operate offshore, it is beyond the reach of U.S. authorities. Such a scenario is ripe for consumer fraud. The greatest danger posed by Internet gambling is that there is no way to control it and there is no way to regulate it.").

123. See, e.g., CAL. Bus. \& Prof. CoDE $§ 19,834$ A(f) (West Supp. 1999).

124. See 18 U.S.C.A. $\$ \$ 1304,1307$ (West Supp. 1998).

125. See, e.g., IOWA CODE ANN. § 99B.17 (West 1996).

126. See, e.g., CAL. BUS. \& PROF. CODE $§ 19,835.5 A(6)$ (West Supp. 1999). 
Internet gambling eludes these safeguards. Because offshore gambling operations are beyond the reach of both state gambling laws and state regulatory laws, there is no way for regulators to ensure fair games and aboveboard accounting practices. Online gamblers already have complained that, although their losses are deducted immediately from their online accounts, their winnings often fail to appear. ${ }^{129}$ In most instances, the individual 'gambler does not know, or have the resources to determine, who exactly the Internet "house" is, further reducing the guarantee of a fair payout. ${ }^{130}$

It also is easy to see how Internet gambling frustrates the state goals of preventing excessive gambling and gambling by addicts and minors. By enabling rampant advertising, it defeats advertising restrictions. By offering gambling in the home at any hour, it defies time and place restrictions. ${ }^{131}$ By allowing gambling by credit card, it allows people to bet, not just to the limit of their wallet or bank account, but to their credit limit. ${ }^{132}$ Additionally, Internet gambling operations have no way to screen out minors, drunks, or habituals, all of whom can easily bypass the primitive and pro forma safeguards that most sites have available. ${ }^{133}$ This raises the prospect of awestruck teenage techno-junkies or their gambling-addicted parents pounding the keyboard at unpoliced Internet gambling sites twenty-four hours a day. ${ }^{134}$ Furthermore, sports gambling, an extremely popular form of

127. See, e.g., N.M. STAT. ANN. $§ 60-2 \mathrm{E}-26$ (E) (Michie 1997); see also Kyl Bill Hearing, supra note 5, at 5 (statement of Sen. Bryan) ("In Nevada, one of our most important gaming regulations is a ban on gambling until age 21.").

128. See, e.g., N.J. STAT. ANN. \& 5:12-71 (West 1996).

129. See Lane Kelley, Betting with Internet Casino Can Be a Real Roll of the Dice, SUNSENTINEL (Ft. Lauderdale, Fla.), Sept. 8, 1997, at 1A; Mark Balestra, What Gives?, Rolling GOOD TIMES (last modified Oct. 23, 1998) <http://www.rgtonline.com/sportspage/ artlisting.cfm/2848> (describing difficulties in collecting winnings from one sports gambling site).

130. See Kyl Bill Hearing, supra note 5, at 11 (statement of James E. Doyle, Att'y Gen., State of Wis.).

131. See Minnesota v. Granite Gate Resorts, No. C6-95-7227, 1996 WL 767431, at *4 (Minn. Dist. Ct. Dec. 11, 1996) (quoting a WagerNet advertisement claiming to offer "a legal way to bet on sporting events from anywhere in the world ...24 hours a day").

132. This is of particular concern if, as some have suggested, "the bulk of gambling revenue, as much as 80 percent comes from a small percentage of gamblers, about 20 percent." See O'BRIEN, supra note 3 , at 5 .

133. See Granite Gate, 1996 WL 767431, at *4; see also Kyl Bill Hearing, supra note 5, at 5 (statement of Sen. Bryan) (" [T]here is no fool-proof way of ensuring that children can't access the Internet gambling site."); id. ("Over the Internet, there is simply no effective way to prohibit access by children.").

134. According to some experts, between four and eight percent of adolescents in North America "'have a very serious gambling problem." O'BRIEN, supra note 3, at 245 (quoting Jeffrey Derevensky, Professor of Child Psychology, McGill University). Sports betting and card playing often "act[ as 'gateways' to other forms of gambling and substance abuse." Id. (quoting Howard Schaffer, Clinical Psychologist, Harvard University Medical School). 
gambling on the Internet, has been shown to be the most potentially addicting form for adults and teenagers alike. ${ }^{135}$

Some argue that the only way to stop problem gambling is to stop problem gamblers and to punish individual offenders instead of pursuing the casinos. The futility of doing so and the difficulty of tracking down individual cybergamblers have led some commentators to declare cybergambling laws unenforceable. ${ }^{136}$ Traditional law enforcement, however, has never focused on the individual gambler. The Wire Wager Act, for instance, is not aimed at individuals but at those "engaged in the business of betting or wagering." ${ }^{137}$ Furthermore, although some state laws forbid individuals to gamble or to transmit "information as to wagers" over the telephone, ${ }^{138}$ such laws are seldom enforced. ${ }^{139}$ The way to control online gambling is the same as the way government has controlled brickand-mortar gambling: at the source.

\section{B. Federal Regulation and Prosecution Avoids Commerce Clause Concerns}

A potentially significant threshold limitation on applying state laws to Internet gambling is the so-called dormant Commerce Clause. ${ }^{140}$ Dormant Commerce Clause jurisprudence forbids individual states-even absent congressional action-from regulating within their borders commerce that is essentially national in character in such a way as to "burden" interstate

135. "According to experts on problem gaming, access to illegal sports betting on the Internet dramatically increases the risk that people will become active, pathological gamblers. The National Council on Problem Gambling reports that sports betting is among the most popular forms of gambling for compulsive gambler [sic] in the United States." Kyl Bill Hearing, supra note 5, at 15 (statement of Jeff Pash, Executive Vice President, NFL).

136. See David Post, Gambling on Internet Laws, AM. LAw., Sept. 1998, at 95 (arguing that tracking individual gamblers "will prove ineffective because these detection mechanisms can so easily be evaded" by disabling the site-recording features of the gambler's hard drive, encrypting an alias, or accessing a remote computer as the "host" for a gambling session).

137. 18 U.S.C. $\$ 1084$ (a) (1994); see also N.Y. PENAL LAW $\$ 225.00-.40$ (McKinney 1989 \& Supp. 1998) (creating a statutory framework under which an individual bettor does not commit a crime for placing bets, but outlawing participation in any gambling operation other than as a player); People v. Giordano, 87 N.Y.2d 441, 446-47 (1995) (interpreting New York's gambling statute). New York's Law of General Obligations $\$ 5-401$, a civil provision, declares "all wagers, bets or stakes ... unlawful" and provides a civil cause of action against a person placing or accepting bets or wagers. N.Y. GEN. OBLIG. LAW § 5-401 (McKinney 1989). Proposed federal legislation would have targeted the individual gambler as well, making it "unlawful for a person knowingly to use the Internet or any other interactive computer service . . . to place, receive, or otherwise make a bet or wager with any person ...." H.R. 4276, 105th Cong. (1998).

138. See, e.g., MASS. GEN. LAws ch. 271, § 17A (1990).

139. See Robbins, supra note 18, at 27.

140. See Kenneth D. Bassinger, Note, Dormant Commerce Clause Limits on State Regulation of the Internet: The Transportation Analogy, 32 GA. L. REV. 889, 920-22 (1998) (analyzing the Louisiana Internet gambling statute and concluding that it "overreaches the boundaries imposed by the Constitution and is ripe for a Commerce Clause challenge," in large part because of its "imprecise language"); Post, supra note 136, at 97 (arguing that dormant Commerce Clause concerns require a national solution to Internet gambling). 
commerce. The classic examples are the "mudguard" and "blowpost" cases that forbid Illinois from requiring interstate trucks to change their mudguards at its borders ${ }^{141}$ and Georgia from forcing interstate trains to stop and blow their whistles at all 124 grade crossings between South Carolina and Florida. ${ }^{142}$

These familiar examples were updated in the digital era by American Libraries Ass'n v. Pataki ${ }^{143}$ in which a federal district court in New York struck down that state's Internet Indecency Act, ${ }^{144}$ which forbade the use of the Internet "to initiate or engage in [sexually explicit] communication with a person who is a minor." ${ }^{445}$ Determining that the resolution of the case "depends on the appropriate analogy," the court found "that the Internet is analogous to a highway or railroad," making "the phrase "information superhighway' ... more than a mere buzzword; it has legal significance, because the similarity between the Internet and more traditional instruments of interstate commerce leads to analysis under the Commerce Clause." ${ }^{146}$ The court concluded that subjecting Web pages to the vagaries of state law "highlights the likelihood that a single actor might be subject to haphazard, uncoordinated, and even outright inconsistent regulation by states that the actor never intended to reach and possibly was unaware were being accessed." ${ }^{147}$ This made the Act "an unconstitutional projection of New York law into conduct that occurs wholly outside New York." ${ }^{148}$ Thus, the court concluded that "the Internet is one of those areas of commerce that must be marked off as a national preserve to protect users from inconsistent legislation that, taken to its most extreme, could paralyze development of the Internet altogether." 149

Some commentators have pointed to American Libraries Ass'n as proof that applying state law to Internet gambling would be unconstitutional under the Commerce Clause and risks the Internet becoming "lost in a welter of inconsistent laws, imposed by different states with different priorities." ${ }^{150} \mathrm{~A}$ related concern is the risk that a tiny, conservative jurisdiction could effectively mold the entire World Wide Web to fit its own moral contours. This threat materialized in 1995, when CompuServe temporarily blocked access worldwide to over 200 Internet sites, after a single prosecutor in

141. See Bibb v. Navajo Freight Lines, 359 U.S. 520 (1959).

142. See Seaboard Air Line Ry. v. Blackwell, 244 U.S. 310 (1917).

143. 969 F. Supp. 160, 169 (S.D.N.Y. 1997).

144. N.Y. PENAL LAW $\$ 235.21$ (3) (McKinney Supp. 1998).

145. Id.

146. American Libraries Ass'n, 969 F. Supp. at 161.

147. Id. at 168-69.

148. Id. at 169.

149. Id.

150. Post, supra note 136, at 97 (citation omitted). 
Munich, Germany, alleged that the sites contained sexual and other material that violated German law. ${ }^{\text {s1 }}$

Dormant Commerce Clause jurisprudence has been considered in other Internet contexts, however, and held not to be an impediment to state action. In People v. Lipsitz, ${ }^{152}$ for instance, the court analyzed and rejected the argument that dormant Commerce Clause concerns prevent the application of New York consumer protection law to an Internet magazine-subscription service operated from a server located in New York, the national nature of the service notwithstanding. It noted that "consumer protection laws... were not designed nor aimed at regulating conduct outside this State's borders" ${ }^{153}$ and that, unlike the statute at issue in American Libraries $A s s ' n$, "these consumer protection statutes are not an attempt to regulate speech on the Internet or create an Internet regulatory scheme." ${ }^{154}$ Thus, the court concluded, "the claims are of local concern, as recognized by the nationwide system of state consumer protection laws." 155

The Lipsitz court was correct that the system of individual state consumer protection laws that has developed since the 1960s never has been thought of as triggering dormant Commerce Clause problems, even when applied to national advertising campaigns. ${ }^{156}$ Moreover, these consumer protection laws have, in fact, been the weapon of choice for states that have challenged the legality of Internet gambling under state law. ${ }^{157} \mathrm{~A}$ problem lurks, however, at the remedy stage. Courts must be careful to craft a statespecific remedy that would not exclude gambling sites from jurisdictions that have not declared them illegal. A Missouri court, for instance, having found that a gambling Web site called Global Casino violated Missouri law, avoided dormant Commerce Clause problems simply by enjoining the

151. See John Markoff, On-Line Service Blocks Access to Topics Called Pornographic, N.Y. TIMES, Dec. 29, 1995, at A1; Paul Taylor, Internet Groups Suspended over Pornography Fears, FIN. TIMES (London), Dec. 29, 1995, at 1.

152. 663 N.Y.S.2d 468 (Sup. Ct. 1997).

153. Id. at 475.

154. Id.

155. Id.

156. The problem of inconsistent or differing standards created by these laws, however, is hardly insignificant. For that reason, courts faced with certifying national class action cases brought under state consumer-protection laws often refuse to do so, because "variations in state laws" make the proposed class unmanageable. See, e.g., Castano v. American Tobacco Co., 84 F.3d 734, 742 \& n.15 (5th Cir. 1996).

157. See Thompson v. Handa-Lopez, Inc., 998 F. Supp. 738 (W.D. Tex. 1998) (alleging that an Internet gambling Web site violated the Texas Deceptive Trade Practices Act by failing to pay winnings); Minnesota v. Granite Gate Resorts, No. C6-95-7227, 1996 WL 767431, at *1 (Minn. Dist. Ct. Dec. 11, 1996) (noting the Minnesota Attorney General's allegation that an Internet advertisement claiming Internet gambling was legal in Minnesota was false advertising under a consumer-protection law), aff'd, 568 N.W.2d 715 (Minn. Ct. App. 1997); Missouri Officials Sue Indian Tribe, Seeking To Shut Down Internet Gambling Site, 2 Elec. Info. Pol'y \& L. Rep. (BNA) 617, 617-18 (June 13, 1997) (discussing Nixon v. Coeur d'Alene Tribe, No. CV-97-013053 (Mo. Cir. Ct. Jackson County May 28, 1997), in which prosecutors alleged that an Internet gambling site was in violation of Missouri's Merchandising Practices Act). 
company from setting up accounts for, and taking bets from, Missouri residents, ${ }^{158}$ much in the same way that some sweepstakes refuse entries from residents of certain states. ${ }^{159}$ When Global Casino, in violation of the injunction, accepted such bets anyway, a criminal indictment was filed against the company's president. ${ }^{160}$

The advantage of the federal approach described earlier ${ }^{161}$ is that, by accommodating each state's individual statutes, both dormant Commerce Clause problems and state policy disputes are avoided. Support for this proposition can be found in the circumstances that led to Pic-A-State. ${ }^{162}$ When Pennsylvania tried to stop Pic-A-State by passing a law that "prohibited the sale [in Pennsylvania] of any interest in another state's lottery," 163 a federal district court struck it down on dormant Commerce Clause grounds. ${ }^{164}$ Congress then passed the Interstate Wagering Amendment, which prohibited the interstate transmission of lottery information. ${ }^{165}$ This "made the Pennsylvania statute fully consistent with federal law and not unduly burdensome on interstate commerce." 166

\section{Personal Jurisdiction and Due Process Concerns Can Be Satisfied}

At first blush, ensuring that federal prosecutions of offshore Internet gambling operators comport with due process raises more complex issues than do other applications of long-arm jurisdiction. In fact, largely because of these jurisdictional problems, one student note has suggested that to try to apply existing gambling statutes to Internet gambling "would be like

158. See Pennsylvania Internet Gambling Operation Enjoined from Soliciting Missouri Residents, 2 Elec. Info. Pol'y \& L. Rep. (BNA) 585, 585-86 (June 6, 1997) [hereinafter Pennsylvania Internet] (discussing Missouri v. Interactive Gaming \& Communications Corp., No. CV 97-7808 (Mo. Cir. Ct. Jackson County May 22, 1997)).

159. For example, a sweepstakes sponsor who failed to post the New York bond would be required to label its sweepstakes "not open to New York residents" to avoid liability under the statute. See N.Y. GEN. BUS. LAW § 369-e(4) (McKinney 1996) (requiring a trust account or bond to be posted with the Secretary of State whenever a sweepstakes prize exceeds $\$ 5000$ ). Similarly, Florida's Secretary of State has opined that Internet sweepstakes that require entrants to subscribe to an Internet service provider are illegal lotteries, because the subscription constitutes consideration. See Michael Barkow, Promotion Law Overview and FAQ $\$$ C (last modified June 24, 1998) <http://www.adlaw.com/RC/SWEEPS/rf_promolaw.html>.

160. See Pennsylvania Internet, supra note 158 , at 585 .

161. See supra notes $56-75$ and accompanying text.

162. Pic-A-State Pa., Inc. v. Reno, 76 F.3d 1294 (3d Cir. 1996).

163. Id. (citing PA. STAT. ANN., tit. 72, \$ 3761-9(c) (West 1995)).

164. See Pic-A-State Pa., Inc. v. Pennsylvania, Civ. A. No. 1: CV-93-0814, 1993 WL 325539 (M.D. Pa. July 23, 1993), rev'd, 42 F.3d 175 (3d Cir. 1994).

165. See supra note 53; see also Pic-A-State Pa., Inc., 42 F.3d at 180 (reversing the district court's order declaring the statute unconstitutional and permanently enjoining its enforcement, on the ground that the Interstate Wagering Amendment had been enacted during the period between the district court's decision and the oral argument in the Third Circuit).

166. Pic-A-State Pa., 76 F.3d at 1297. 
'performing brain surgery with stone tools."' 167 Recent cases, however, have significantly clarified the analysis.

One initial concern regarding personal jurisdiction and the Internet was whether the operator of an Internet site could, without suspecting it, be subject to prosecution in any jurisdiction from which the site could be accessed, raising the specter of potential jurisdiction worldwide. That is not the way the law has evolved, however, and properly so. Instead, employing the traditional two-pronged analysis, courts ask, first, whether there are sufficient contacts to ensure that in-state effects are sufficiently foreseeable for the site operator to have to defend a lawsuit there and, second, whether an assertion of jurisdiction is fair under due process. ${ }^{168}$

Moreover, in recent cases, courts have focused not just on whether an Internet transmission has occurred, but on the types of transmissions involved. In so doing, they have developed a continuum, whereby personal jurisdiction can be asserted over a Web site operation depending on the degree of interactivity the site allows or encourages with users in the forum state. ${ }^{169}$ At one end of the continuum, courts generally do not find personal jurisdiction over purely passive Web sites that simply provide information to users. ${ }^{170}$ In the middle are advertising sites that may list a toll-free number or otherwise more actively solicit business. These sites present close calls, and the decisions involving them are extremely fact-specific and go either

167. Gorman \& Loo, supra note 18, at 708 (quoting I. Nelson Rose, Wire Cops: The A.G.'s Take on Internet Gambling, CASINO EXECUTIVE, Aug. 22, 1995, at 22).

168. See Burger King Corp. v. Rudzewicz, 471 U.S. 462, 475 (1985); World-Wide Volkswagen v. Woodson, 444 U.S. 286, 295 (1980). For examples of Internet-related cases taking this two-pronged approach, see infra notes 170-171.

169. See Zippo Mfg. v. Zippo Dot Com, Inc., 952 F. Supp. 1119, 1123-24 (W.D. Pa. 1997).

170. For instance, the Web site at issue in Bensusan Restaurant Corp. v. King, 937 F. Supp. 295, 297 (S.D.N.Y. 1996), aff'd, 126 F.3d 25 (2d Cir. 1997), simply contained "general information about the [night]club in Missouri as well as a calendar of events and ticketing information." See also Cybersell, Inc. v. Cybersell, Inc., 130 F.3d 414, 419 (9th Cir. 1997) (dismissing for lack of personal jurisdiction an action brought in Arizona against a company that had no contacts with the forum state other than maintaining "an essentially passive home page on the [W]eb," which was accessible by anyone and from anywhere, and holding there must be " 'something more' to indicate that the defendant purposefully (albeit electronically) directed his activity in a substantial way to the forum state"); Scherr v. Abrahams, No. 97 C 5453, 1998 WL 299678 , at $\div 4$ (N.D. Ill. May 29, 1998) (holding that where advertising on the defendant's Web site was not specifically targeted at Illinois consumers, contacts were not sufficient to create jurisdiction over the defendant); Blackburn v. Walker Oriental Rug Galleries, 999 F. Supp. 636, 639 (E.D. Pa. 1998) (holding that a "passive" Web site featuring the defendant's national advertising is not sufficient contact with a forum for an exercise of personal jurisdiction); SF Hotel Co. v. Energy Invs., 985 F. Supp. 1032, 1035 (D. Kan. 1997) (holding that, in a trademark infringement case involving the mark "Sierra Suites," a passive Web site that "provides general information about its hotel" did not support personal jurisdiction over the Florida defendant); Transcraft Corp. v. Doonan Trailer Corp., No. 97 C 4943, 1997 WL 733905, at *8-*10 (N.D. IIl. Nov. 12, 1997) (refusing to exercise personal jurisdiction over a Kansas defendant based on the existence of a passive Web site and several other commercial activities allegedly connected with Illinois); Agar Corp. v. Multi-Fluid Inc., No. 95-5105, 1997 WL 829340 (S.D. Tex. June 25, 1997) (refusing to exercise personal jurisdiction over a Norwegian defendant based on its passive Web site and several other tenuous links to Texas). 
way, sometimes depending on whether the Web sites constitute "passively informational, rather than solicitous advertisements." 171 At the far end of the spectrum are sites that interact with users and conduct business online. ${ }^{172}$ Courts have had little difficulty finding jurisdiction in these situations.

The best argument as to why Internet gambling operators should not be subject to personal jurisdiction in every venue from which their sites are accessed is a variation on an argument made by Professor Dan L. Burk: Because the Internet does not permit Web site operators to discriminate by jurisdiction, "its contacts with any given jurisdiction are less, rather than more purposeful." 173 Gambling site operators simply will contend that they cannot possibly know where individuals visiting their sites reside.

Whatever the merits of Burk's concerns in the abstract, they seem misplaced given the realities of Internet gambling. In virtually all cases in which actual bets have been accepted, ample facts will support the argument that the operators knew exactly where their customers lived and had sufficiently significant contacts to satisfy a purposeful availment analysis. ${ }^{174}$ For example, in Thompson $v$. Handa-Lopez, Inc., ${ }^{175}$ a lawsuit commenced by a Texas resident to recover $\$ 193,728.40$ in winnings from a California gambling Web site, the court found that the exercise of jurisdiction was proper in light of what it characterized as "more extensive interaction" than

171. Shapiro v. Santa Fe Gaming Corp., No. 97 C 6117, 1998 WL 102677, at *2 (N.D. IIl. Feb. 27, 1998) (characterizing the law as well-settled that the maintenance of a toll-free telephone number and a passive, non-advertising Web site, "without more, is insufficient to satisfy jurisdiction"); see also Bunn-O-Matic Corp. v. Bunn Coffee Serv., No. 97-3259, 1998 WL 207860 (C.D. Ill. Apr. 1, 1998) (holding that a "passive" Web site constitutes "entry" into a forum); Hasbro, Inc. v. Clue Computing, 994 F. Supp. 34, 41-42, 43-44 (D. Mass. 1997) (expressing concern over cases holding that the existence of a Web site alone is sufficient to allow jurisdiction but noting that, in the case before it, the injury occurred in Massachusetts and defendants solicited business there by, inter alia, soliciting e-mail contacts); Superguide Corp. v. Kegan, 987 F. Supp. 481, 487 (W.D.N.C. 1997) (exercising personal jurisdiction over an out-of-state defendant based solely on the accessibility in North Carolina of the defendant's Web site); Smith v. Hobby Lobby Stores, 968 F. Supp. 1356, 1364 (W.D. Ark. 1997) (requiring that, to be subject to jurisdiction, Web site advertising be actively solicitous, thus preventing the chaotic conclusion "that a company is subject to personal jurisdiction at each and every location on the planet where someone is capable of logging on the Internet"); Inset Sys. v. Instruction Set, Inc., 937 F. Supp. 161,165 (D. Conn. 1996) (finding a Web site that listed a toll-free number subject to jurisdiction because advertising via the Internet was solicitation of a sufficient repetitive nature).

172. See CompuServe, Inc. v. Patterson, 89 F.3d 1257, 1268 (6th Cir. 1996) (finding jurisdiction where a Web site user actively communicated with an online service and used it to sell his software over the Internet); Mieczkowski v. Masco Corp., 997 F. Supp. 782, 787 (E.D. Tex. 1998) (finding adequate jurisdiction exercised where remote customers would view purchases online, check their status, and communicate with a sales representative).

173. Burk, supra note 10, $\$ 54$.

174. For a general discussion of purposeful availment, see Hanson v. Denckla, 357 U.S. 235, 253 (1958). See also Burger King v. Rudzewicz, 471 U.S. 462, 474-76 (1985) (holding that the deliberate creation of contacts with a particular jurisdiction satisfies the personal jurisdiction test). The Southern District of New York complaints reveal that many gambling site operators specifically request information about their customers' locations. See Sealed Complaint II 11, United States v. Moore, No. 98-m-00677) (S.D.N.Y. Mar. 24, 1998) ("www.galaxysports.com").

175. 998 F. Supp. 738 (W.D. Tex. 1998). 
in those cases at the beginning and middle of the continuum. ${ }^{176}$ It specifically noted that the defendant "continuously interacted with the casino players, entering into contracts with them ... knowing it would receive commercial gain" from them, that Texas residents played those games "as if they were physically located in Texas," and that any winnings were ultimately to be delivered to Texas. ${ }^{177}$

Moreover, it is difficult to argue that Internet casino and sports-betting sites that advertise both online and in national magazines, collect wagers from and transmit winnings to the United States, and post odds and scores on professional sporting events in the United States do not subject themselves to jurisdiction in every state where their patrons cut the virtual cards. There is a huge difference between the abstract, technological possibility that a site will be accessed from a given location-a prospect that, in and of itself, ordinarily should not trigger jurisdiction-and the undisputed fact that before any gambling occurs, an Internet gambling site will have taken many steps to make sure it gets money from the gamblers. ${ }^{178}$

\section{U.S. Criminal Law Reaches Offshore}

Commentators ${ }^{179}$ and cybercasino operators ${ }^{180}$ have expressed concerns that American efforts to curb Internet gambling may interfere with the laws of other countries. They argue that most Internet gambling sites are properly licensed in countries such as Costa Rica and Antigua, where they support

176. Id. at 744 .

177. Id. According to the court, the plaintiff "entered into a contract to play the game on Defendant's Web site," id. at 741, under which "the Defendant would send the winnings to the Plaintiff in Texas," id. at 744. But cf. Humphrey v. Granite Gate Resorts, Inc., 568 N.W.2d 715, 719 (Minn. Ct. App. 1997) (holding that long-arm jurisdiction was properly exercised over defendants located in Nevada, who operated an Internet casino with a server in Belize, based on transmissions of information advertising the casino, even though no betting transactions occurred).

178. See infra notes 196-209 and accompanying text (detailing the contacts of Internet gambling sites with their customers' jurisdictions in the Southern District of New York complaints). In addition to jurisdictional due process concerns, there also is the due process issue of whether, prior to the first Internet gambling prosecutions, Internet gambling operators had fair notice that their operations were condemned by $\$ 1084$. Given the breadth of $\S 1084$, its prior application to the offshore, telephone-based equivalents of Internet gambling, the legislative history indicating its applicability to all forms of gambling operations relying on "wire communications facilities," and the number of articles noting the possibility of prosecutions under $\S 1084$, it is difficult to argue they did not. Absent a showing that the statute is void for vagueness-and $\$ 1084$ has survived challenges on that basis, see United States v. Borgese, $235 \mathrm{~F}$. Supp. 286, 295-97 (S.D.N.Y. 1964); United States v. Smith, 209 F. Supp. 907, 918 (E.D. IIl. 1962)-misjudging the scope of $\$ 1084$ does not create a due process issue. Nor does such misjudging establish a lack of requisite intent. See United States v. Spy Factory, Inc., 960 F. Supp. 684, 687-88 (S.D.N.Y. 1997) (distinguishing between statutes that set forth knowledge of a specific legal duty as an element of a crime and those that do not and applying the well-established maxim that, in the latter case, "ignorance of the law is no excuse").

179. See sources cited supra note 18 .

180. See Kyl Bill Hearing, supra note 5, at 41-43 (statement of Jay Cohen, President \& CEO, World Sports Exch.). 
the local economy by paying up to $\$ 100,000$ in license fees alone to do business. ${ }^{181}$ Any interference, they maintain, would violate the sovereignty of those host countries and smack of colonialism. ${ }^{182}$

Such concerns ignore both legal and practical realities. The offshore reach of U.S. criminal law is well established. ${ }^{183}$ Some laws, for instance, apply by their specific terms to acts "committed outside the territorial jurisdiction of the United States." 184 Others, including the Wire Wager Act, ${ }^{185}$ the Travel Act, ${ }^{186}$ and the ITWPA, ${ }^{187}$ criminalize acts involving "interstate or foreign commerce" that permit or aid gambling, ${ }^{188}$ which strongly implies extraterritorial application. ${ }^{189}$ American laws also have been applied to foreign criminal activities that affect the United States. This concept is not new; in Horwitz v. United States, the defendants were prosecuted for conducting a lottery over the radio from a station located in Mexico that solicited participation by, inter alia, residents of Texas. ${ }^{190}$ In colorful language, the concurring opinion stated: "If [a] pistol ... takes intended criminal effect from Mexico in the United States, the United States may punish .... [M]ailed lottery receipts and checks are like bullets that hit their mark." 191 Such "effects" tests also have allowed courts to find extraterritorial jurisdiction over a Panamanian dictator accused of violating U.S. drug laws ${ }^{192}$ and over defendants who entered into fraudulent marriages

181. See 2 CABOT, supra note 4 , at 73 .

182. "There's a terrible stigma attached to everything that is done in this quarter of the world [and that] give[s] rise to a feeling that we couldn't possibly ... run a virtual gaming operation on a level that would be acceptable to the standards of the United States. ... [O]perators in Antigua and Barbuda are subject to the laws of Antigua and Barbuda and they are not subject to any laws which are not identifiable under a specific treaty with the United States." $A B C$ Nightline (ABC television broadcast, Apr. 7, 1998) (interview with Jeannette McAlister, Antiguan international investment worker).

183. See Robbins, supra note 18 , at 41 ; Gorman \& Loo, supra note 18 , at 686 .

184. 21 U.S.C. $\$ 959$ (1994) (proscribing "[p]ossession, manufacture, or distribution of controlled substance or listed chemical"). "Section 959, prohibiting the distribution of narcotics intending that they be imported into the United States, is clearly meant to apply extraterritorially. The statute expressly states that it is intended to reach acts of manufacture or distribution committed outside the territorial jurisdiction of the United States." United States v. Noriega, 746 F. Supp. 1506, 1515 (S.D. Fla. 1990) (quoting 21 U.S.C. $\$ 859$ (c)), aff d, 117 F.3d 1206 (11th Cir. 1997), cert. denied, 118 S. Ct. 1389 (1998).

185. 18 U.S.C. $\$ 1084$ (1994).

186. Id. $\$ 1952$.

187. Id. $\$ 1953$.

188. Id. \$ 1953(a).

189. See Noriega, 746 F. Supp. at 1518-19 (noting that the broad statutory language of the Travel Act is intended "to reach criminal activities ... beyond state and national borders" and applies if "the defendant causes interstate travel or activity to promote an unlawful purpose ... whether or not the defendant is physically present in the United States").

190. 63 F.2d 706 (5th Cir. 1933).

191. Id. at 709 (Sibley, J., concurring).

192. See Noriega, 746 F. Supp. at 1515 ("[B]ecause Noriega's conduct in Panama is alleged to have resulted in a direct effect within the United States, the Court concludes that extraterritorial jurisdiction is appropriate as a matter of international law."). 
abroad in order to enter the United States illegally. ${ }^{193}$ Additionally, U.S. criminal laws have been found to reach acts occurring abroad, if "part of the offense[] occurred within the United States," ${ }^{194}$ as in the case of an Italian citizen who sent child pornography from Italy to an American address, partially via U.S. mail. ${ }^{195}$ In short, it has long been accepted that the United States may, in appropriate cases, use its domestic law to prosecute internationally-based criminal acts.

Furthermore, as a practical matter, many, if not most, of the cybercasinos are not the product of a native cottage industry. Instead, they typically involve U.S. residents alighting on foreign soil and targeting their fellow citizens from abroad. Their U.S. contacts are not limited to cyberspace. As the complaints filed in the Southern District of New York show, gambling sites require numerous non-cyber contacts with U.S. citizens, all of which involve the instrumentalities of interstate commerce and therefore violate federal law. For instance, the investigations of SDB Global and World Sports Exchange revealed the following U.S. contacts:

- The companies advertised nationally in College \& Pro Football Newsweekly and Pro Football Weekly. ${ }^{196}$

- A letter and brochure describing SDB Global and telling how to open an account bore the return address "SDB Global, S.A., 82 Wall Street, New York, New York 10005," 197 where SDB Global had offices and did its marketing. ${ }^{198}$ Other literature was mailed from Miami. ${ }^{199}$ Information about World Sports Exchange was mailed to New York from California. ${ }^{200}$

- To open an account, SDB required a money transfer via Bankers Trust in New York. ${ }^{201}$ World Sports Exchange required its users to

193. See Rocha v. United States, 288 F.2d 545, 548 (9th Cir. 1961) (finding that jurisdiction "rested not only on the act abroad, but also on the effect it produced within the boundaries of the United States").

194. United States v. Moncini, 882 F.2d 401, 403 (9th Cir. 1989).

195. See id. (holding that the crime continued as the letter traveled through the mail and reached its U.S. destinations and was not "complete at the time the letter was deposited in the mail in Italy").

196. See Sealed Complaint II 29, United States v. Budin, No. 98-m-00463 (S.D.N.Y. Mar. 2, 1998) ("www.sdbg.com"); Sealed Complaint III 24-25, United States v. J. Cohen, (No. 98-m00465 (S.D.N.Y. Mar. 2, 1998) ("www.wsex.com").

197. See Sealed Complaint II 9, United States v. Budin, No. 98-m-00463 (S.D.N.Y. Mar. 2, 1998) ("www.sbdg.com").

198. See id. 匢 22-23.

199. See id. II 11.

200. See Sealed Complaint $\mathbb{I}$ 20e n.4, United States v. J. Cohen, No. 98-m-00465 (S.D.N.Y. Mar. 2, 1998) ("www.wsex.com").

201. See Sealed Complaint II 11, United States v. Budin, No. 98-m-00463 (S.D.N.Y. Mar. 2, 1998) (“www.sbdg.com"). 
transfer money via Western Union, ${ }^{202}$ and maintained an account at Chase Manhattan Bank in New York, through which wire transfers were made to Antigua. ${ }^{203}$

- Money from a customer's SDB account was sent to New York from an address in North Miami Beach, Florida, and was payable through a bank in Miami. ${ }^{204}$ Checks payable through the Chase Manhattan Bank in New York City were received in New York from World Sports Exchange via Federal Express. ${ }^{205}$

- The toll-free number over which SDB accepted bets was registered to a person in Aventura, Florida ${ }^{206}$ and showed calls from all over the United States. ${ }^{207}$ The World Sports Exchange toll-free number was provided by an exchange in Mississippi and registered to a person in Georgia. ${ }^{20 s}$

- Dun \& Bradstreet listed SDB Global as based in Miami. ${ }^{209}$

These non-Internet contacts with the United States do not appear to be either incidental or avoidable. Although in the future it may be possible to do business with U.S. customers from Antigua without using U.S. banks, U.S. mails, U.S. publications, U.S. telephones, and U.S. addresses, that day is not here. As long as Internet gambling sites have to attract American customers, who account for over fifty percent of Internet use, ${ }^{210}$ these contacts are inevitable, and they inevitably provide both a substantive basis for federal prosecution and an ample foundation for the assertion of jurisdiction over criminal defendants.

202. See Sealed Complaint II 10, United States v. J. Cohen, No. 98-m-00465 (S.D.N.Y. Mar. 2,1998 ) ("www.wsex.com").

203. See id. $\mathbb{2} 23$.

204. See Sealed Complaint II 18, United States v. Budin, No. 98-m-00463 (S.D.N.Y. Mar. 2, 1998) ("www.sbdg.com").

205. See Sealed Complaint III 16, 18, United States v. J. Cohen, No. $98-m-00465$ (S.D.N.Y. Mar. 2, 1998) ("www.wsex.com").

206. See Sealed Complaint II 18, United States v. Budin, No. 98-m-00463 (S.D.N.Y. Mar. 2, 1998) ("www.sbdg.com").

207. See id. $\llbracket 28$.

208. See Sealed Complaint III 21-22, United States v. J. Cohen, No. $98-m-00465$ (S.D.N.Y. Mar. 2, 1998) ("www.wsex.com").

209. See Sealed Complaint II 26, United States v. Budin, No. 98-m-00463 (S.D.N.Y. Mar. 2, 1998) ("www.sbdg.com").

210. See Computer Industry Almanac Inc., Top 15 Countries with the Most Internet Users, (last modified Jan. 1998) <http://www.c-i-a.com/199801pr.htm>. 


\section{E. Antigambling Statutes Can Be Applied to Cyberspace as Readily as Other Laws}

Arguments that the Internet requires a different legal regime rely on the assumption that its unique characteristics will make it difficult, if not impossible, for courts to apply existing laws sensibly in the digital era. ${ }^{211}$ That assumption is seriously overstated. Rather than accepting it uncritically, the inquiry should be whether there is anything unique about the use of the Internet for gambling that should inhibit its prosecution under current law in jurisdictions where other, non-digital gambling is illegal.

The more the mechanics of Internet gambling are reviewed, ${ }^{212}$ the more it appears to be a new-media imitation of what federal law has long condemned when practiced via other communications media, such as the telephone and $\mathrm{fax}^{213}$ This renders gambling quite amenable to the traditional kind of media-neutral approach used in intellectual property law. Media-neutral application of law is familiar in copyright, for instance, largely because of the extraordinary effort made to ensure that the Copyright Act of 1976 would work well in the digital age. For that reason, the "subject matter of copyright" is defined as "original works of authorship fixed in any tangible medium of expression, now known or later developed, from which they can be perceived, reproduced, or otherwise communicated, either directly or with the aid of a machine or device." 214 The media-neutrality of copyright law is further reflected in its legislative history: "Authors are continually finding new ways of expressing themselves, but it is impossible to foresee the forms that these new expressive methods will take." ${ }^{215}$ The following characterization of the nation's copyright laws therefore remains apt in the information age:

[Y] ou can read the bill from beginning to end and you won't find in it any reference to computers, for example. Yet these are one of the coming instruments of communication in the future. We have tried to phrase the broad rights granted in such a way that they can be adapted as time goes on to each of the new advancing media. ${ }^{216}$

211. See Burk, supra note 10, I 6; Johnson \& Post, supra note 10, at 1367.

212. See supra notes $165-178$ and accompanying text.

213. See Hardy, supra note 17 , at 1000 .

214. 17 U.S.C. $\$ 102$ (a) (1994). The Act further defines a "device" or "machine" as "one now known or later developed." Id. \$ 101.

215. H.R. REP. NO. 94-1476, at 51 (1976).

216. Copyright Law Revision: Hearings on H.R. 4347, 5680, 6831, 6835 Before Subcomm. No. 3 of the House Comm. on the Judiciary, 89 th Cong. 57 (1965) (statement of George D. Cary, Deputy Register of Copyright). Further, although the concept of fixation was, from the outset, the sine qua non for protection under the new Act, "it makes no difference what the form, manner, or medium of fixation may be-whether it is in words, numbers, notes, sounds, pictures, or any other graphic or symbolic indicia, whether embodied in a physical object in written, printed, 
A recent decision illustrates the importance of the media-neutrality of the Copyright Act. In 1993, a coalition of freelance writers sued the New York Times and other major publications for including their contributions in the electronic editions of periodicals made available on the Lexis-Nexis electronic research database and in CD-ROM format. In Tasini v. New York Times, ${ }^{217}$ the court ruled in favor of the publications, finding that the electronic versions of the periodicals in dispute fell within the "any revision" language of section 201(c) of the Copyright Act, which grants publishers the "right to revise their collective works," including transforming them into digital versions. ${ }^{218}$ The court noted the lengths to which Congress went to study the impact of computers on copyright ${ }^{219}$ to ensure that it had drafted a media-neutral statute. It concluded that "it is to be presumed that the terms of the 1976 Act encompass all variety of developing technologies." 220

Even without such specific guidance from Congress, courts have applied the Copyright Act in a media-neutral way. For example, in Religious Technology Center v. Netcom On-Line Communication Services, ${ }^{221}$ Netcom, an Internet service provider, was accused of infringing copyrights in Scientology tracts by providing Internet access to a computer bulletin board service on which portions of those works were stored. ${ }^{222}$ The court rejected the argument that such storage made Netcom directly liable for copyright infringement. Instead, it analogized Netcom to "the owner of a copying machine who lets the public make copies with it" ${ }^{223}$ and held that direct infringement requires "some element of volition or causation which is lacking where a defendant's system is merely used to create a copy by a third party." ${ }^{224}$ By refusing to construe the Act so literally, the court refrained from penalizing Internet users and operators who had done no

photographic, sculptural, punched, magnetic, or any other stable form." H.R. REP. No. 94-1476, at 52 (1976).

217. 972 F. Supp. 804 (S.D.N.Y. 1997). The author, along with others at Debevoise \& Plimpton, represented the defendants in this case.

218. See id. at 826-27.

219. See, e.g., NATIONAL COMM'N ON NEW TECHNOLOGICAL USES OF Copyrighted WORKS, FINAL REPORT (1978).

220. Tasini, 972 F. Supp. at 818; cf. Ryan v. Carl Corp., 23 F. Supp.2d 1146, 1149-50 (N.D. Cal. 1998) (concluding that 17 U.S.C. \$ 201(c) (1994) does not permit the republication of individual contributions apart from other contributions in the original or revised collective work, but questioning the equities and societal inefficiencies of such a result).

221. 907 F. Supp. 1361, 1365 (N.D. Cal. 1995).

222. See id. at 1367-68.

223. Id. at 1369.

224. Id. at 1370 . The wisdom of the Netcom decision did not escape Congress, which recently amended the Copyright Act to compel the same conclusion. See Digital Millennium Copyright Act, $\$ 202$ (a), 112 Stat. 2860, 2877-86 (1998) (to be codified at 17 U.S.C. \$ 512). 
more than "implement a system that is essential if Usenet messages are to be widely distributed." 225

The media-neutral application of old laws to Internet activities is no more difficult in the criminal context. In People v. Lipsitz, ${ }^{226}$ the court held that a magazine subscription scheme that aggressively marketed to members of "listservs" ${ }^{227}$ but did not deliver the subscriptions as promised could be prosecuted for fraud. Responding to its own inquiry as to whether there were Internet-related reasons why such a scheme should not be prosecuted in New York, the court placed the question in a "realistic context . . leav[ing] behind the rarified air of cyberspace" and concluded:

There is no compelling reason to find that local legal officials must take a "hands off" approach just because a crook or a con artist is technologically sophisticated enough to sell on the Internet. Invocation of "the Internet" is not the equivalent to a cry of "sanctuary" upon a criminal's entry into a medieval church. It should be sufficient that the laws sought to be applied.... are "media neutral" and otherwise pass constitutional muster. ${ }^{228}$

The Justice Department struck a similar note in explaining its decision to prosecute Internet gambling under the Wire Wager Act, maintaining that $\S 1084$ applies equally to the Internet as to any "wire communication facility" that was in existence when the Act was passed. In fact, U.S. Attorney General Janet Reno, in announcing the arrests and complaints, used language strikingly similar to the Lipsitz opinion:

The Internet is not an electronic sanctuary for illegal betting. If a state outlaws soliciting or accepting bets, you can't evade those requirements by going on-line. It's a federal crime to use the Internet to conduct betting operations. And to Internet betting operators everywhere we have a simple message; You can't hide on-line and you can't hide off-shore. ${ }^{229}$

Some commentators disagree with Attorney General Reno's assertion, however, suggesting that the ability of Internet gambling operators to hide, both on-line and off-shore, makes enforcement impossible and, therefore,

225. Netcom, 907 F. Supp. at 1370 . The Usenet is " a worldwide community of electronic [bulletin board services] that is closely associated with the Internet and with the Internet community." Id. at 1365 n.4.

226. 663 N.Y.S.2d 468 (Sup. Ct. 1997).

227. A "listserv" is an e-mail discussion group. Id. at 471.

228. Id. at 475 .

229. United States Attorney, supra note 106. The SEC also has vigorously pursued individuals and companies who use the Internet to promote stocks in ways that violate the securities laws. Since 1995, when it began to police the Internet, it has brought a total of 61 on-line fraud and related cases. See SEC Charges 44 Internet Stock Promoters with Fraud, Dow JONES INTERACTIVE BUS. \& FIN. REP., Oct. 28, 1998, at *2 [hereinafter SEC Charges]. 
makes any legislation in this area an empty gesture. ${ }^{230}$ By disguising their on-line identities, they argue, gambling operators may escape detection and identification altogether; by moving themselves and their assets from account to account and country to country, they may make such assets untraceable and unattachable; by remaining permanently offshore, they may, short of kidnapping or extradition, escape U.S. law entirely.

There are two problems with these arguments. First, thus far, it is impossible even to register a domain name or establish a Web site anonymously, if only because registration services require reliable billing information. ${ }^{231}$ Web site operators necessarily leave footprints, ultimately making them vulnerable to the same investigative techniques that law enforcement has traditionally used-including sting operations and sham accounts opened by undercover operatives. ${ }^{232}$

Second, investigative techniques do not appear to have lagged behind in cyberspace. As early as $1995, \mathrm{FBI}$ and state authorities cooperated in a sting operation on the Internet, whereby agents posing as minors developed enough incriminating evidence to arrest a dozen online child pornographers. ${ }^{233}$ Additionally, the SEC, FTC, and state attorneys general offices have long been active in monitoring and investigating Internet fraud schemes. ${ }^{234}$ There is every reason to expect that, just as Internet gambling

230. See, e.g., Robbins, supra note 18 , at 51 ("Unlike traditional illegal gambling operations, which require a secure and readily accessible location for customers, Internet casino operations can move from country to country while maintaining the same Web site."); Richard Raysman \& Peter Brown, Cyber-Casinos: Gambling Meets the Internet, N.Y. L.J., Aug. 12, 1997, at 3 (" $[U]$ nlike traditional casinos, operators of cyber-casinos have the ability to move from country to country, since operation of a cyber-casino merely requires maintenance of a Web site."); Kelly Flaherty, Feds' Internet Bet Case Avoids 'Cyber' Issues, L.J. EXTRA! II 13 (Mar. 6, 1998) <http://www.ljextra.com/internet/0306betjuris.html> ("[If gambling site operators] choose to remain outside the U.S. and don't have any financial assets within American borders, they may be effectively out of reach of the justice system. Or they could view the fines as a cost of doing business.").

231. See, for example, Network Solutions, Inc.'s Domain Name Registration Policies, which require the name, address, phone, fax and e-mail address of an "administrative contact" for each registrant, see Network Solutions, Inc., Domain Name Registration Agreement $\$$ Q (last modified Mar. 1998) <ftp://rs.internic.net/templates/domain-template.tx $\triangleright$, who can "answer non-technical questions about the legal entity's plans for using the domain name and the procedures for establishing sub-domains," Domain Name Registration Agreement (Version 4.0) Instructions (last modified Mar. 30, 1998) <http://rs.internic.net/help/instructions.txt required for "technical" and "billing" contacts. See Network Solutions, Inc., supra, § Q.

232. See, e.g., Sealed Complaint II 18, United States v. B. Cohen, No. $98-\mathrm{m}-00462$ (S.D.N.Y. Mar. 2, 1998) ("www.wsex.com").

233. See David Johnston, Use of Computer Network for Child Sex Sets off Raids, N.Y. TIMES, Sept. 14, 1995, at A1.

234. See, e.g., Dominic Bencivenga, Internet Cyberforce: SEC and FTC Crack Down on Online Fraud, N.Y. L.J., Sept. 3, 1998, at 5 ("SEC employs a cyberforce that includes more than 100 staff attorneys, analysts and accountants who over the past few years have received special training in Intemet surveillance.... More than 300 [FTC] staff members, including attorneys and investigators, have been trained in Internet surveillance...."); see also Christopher Wolf \& Scott Shorr, Cybercops Are Cracking Down on Internet Fraud, NAT'L L.J., Jan. 13, 1997, at B12 (detailing SEC, FTC, and state Internet prosecutions). 
operators grow more sophisticated, so too will law enforcement's ability to reach them, uncover their true identities and assess their contacts with U.S.based gamblers. As one FTC investigator recently put it:

Some people make a little too much of the fancy nature of the Net.... [Internet operators] have real names, real addresses and telephone numbers and they want their money .... Always follow the money. That basic premise still holds. ${ }^{235}$

\section{CONCLUSION}

This Essay has set forth two reasons why it is wrong to contend that Internet gambling facilitated by Web sites based offshore cannot be prosecuted under existing federal law. ${ }^{236}$ First, such arguments fail to appreciate the long history of successful federal prosecution of gambling operations conducted by earlier long distance communication methods. ${ }^{237}$ Second, and more significantly, they fail to recognize that Internet gambling sites use the Internet only as an instrument to commit a very traditional crime. In other words, nothing about the Internet makes illegal gambling any different from gambling carried on and successfully prosecuted via the mail, a telegraph, a telephone, or a fax machine. ${ }^{238}$ Therefore, this Essay has characterized Internet gambling as a media-neutral offense. ${ }^{239}$

Other laws, both civil and criminal, are similarly media-neutral and can be applied to Internet activity without the need for new models or legal regimes. ${ }^{240}$ In the criminal context, as long as the Internet is not the object or

235. Bencivenga, supra note 234, at 5 (quoting Jodie Bernstein, Director, FTC Bureau of Consumer Protection) (alteration in original).

236. See supra notes 8-18 and accompanying text.

237. See generally supra Part III.

238. See Sheri A. Dillon et al., Computer Crimes, 35 AM. CRIM. L. REV. 503, 504 (1998) (distinguishing between traditional crimes committed with a computer and "technologically specific offenses that are arguably not analogous to any non-computer crimes").

239. See supra note 17 and accompanying text.

240. See supra notes $216-239$ and accompanying text. According to the FTC, "commerce on the Internet falls under the broad sweep of [its] statutory mandate," which is "to protect consumers from unfair or deceptive acts or practices." Electronic Commerce-Part 3: Hearings Before the Telecomm., Trade, and Consumer Protection Subcomm. of the House Comm. on Commerce, 105th Cong. 245 (1998) (statement of Eileen Harrington, Assoc. Dir., Bureau of Consumer Protection, FTC). Although "[m]ost of the Commission's law enforcement actions ... have involved old-fashioned scams dressed up in high-tech garb," id. at 247, the FTC's traditional "unfair deceptive acts and practices" standard has proved media-neutral enough to derail "one scheme that uniquely and ingeniously exploited what can be done on the Internet and only on the Internet," id. at 249 (describing FTC v. Audiotex Connection, Inc., No. CV-97 0726 (DRH) (E.D.N.Y. Nov. 13, 1997), in which the FTC obtained a stipulated permanent injunction against "a scheme that 'hijacked' consumers' computer modems by surreptitiously disconnecting them from their local Internet Service Provider ... and reconnecting them to the Internet through a high-priced international modem connection, purportedly going to Moldova but actually terminating in Canada"). 
subject of the crime ${ }^{241}$ but is instead the instrument by which an otherwise criminal act is committed, it is difficult to comprehend why any new legal regime is necessary.

United States $v$. Thomas ${ }^{242}$ demonstrates how traditional law can be applied in a media-neutral way to crimes facilitated via the Internet. In Thomas, two defendants, both California residents, were convicted in Tennessee for transmitting to Tennessee obscene material via their bulletin board service. A postal inspector in Memphis, Tennessee, joined that service under an assumed name; he subsequently received images over interstate telephone lines and by mail that depicted a wide variety of sexual conduct, including bestiality and excretory fetishism. A jury determined that the materials were obscene under Memphis's "contemporary community standards." 243

The Thomases' convictions were upheld by the Sixth Circuit. The panel rejected the argument that the Thomases should have been judged by the community standards of California rather than Tennessee, citing evidence that the Thomases, knowing the undercover postal inspector was located in Memphis, nonetheless made a conscious decision to permit him to subscribe to their service.

The application of Tennessee's community standards to an obscenity prosecution of California residents has been criticized on several grounds. ${ }^{244}$ Whatever the ultimate wisdom of the result in Thomas, which the Sixth Circuit took care to depict as fact specific, ${ }^{245}$ the case further illustrates the

241. See Dillon et al., supra note 238, at 507 (arguing that the computer is the "object" of a crime when the offender targets the computer itself, as in theft of computer processor time or computerized services, the "subject" of a crime when it is the site of, source of, or reason for, "unique forms of asset loss," as in the distribution of viruses, or an "instrument" used to commit traditional crimes).

242. 74 F.3d 701 (6th Cir. 1996).

243. Id. at 706, 710. The Thomases were also convicted of sending obscene videotapes across state lines. See id. at 706.

244. See, e.g., Debra D. Burke, Cybersmut and the First Amendment: A Call for a New Obscenity Standard, 9 HARV. J.L. \& TECH. 87, 126 (1996) (arguing that imputing to every network user the knowledge of hundreds of contemporary community standards "is simply unrealistic"); Pamela A. Huelster, Cybersex and Community Standards, 75 B.U. L. REv. 865 (1996) (suggesting, inter alia, that local standards should give way to a single, national obscenity standard for computer bulletin board services); Glenn Harlan Reynolds, Virtual Reality and "Virtual Welters": A Note on the Commerce Clause Implications of Regulating Cyberporn, 82 VA. L. REV. 535, 536 (1996) (suggesting that, in addition to First Amendment concerns, the Commerce Clause presents "serious difficulties" for locality-based regulation of computer bulletin board systems).

245. The Sixth Circuit was able to distinguish, on the facts before it, the Thomases' conduct from "a situation where the bulletin board operator had no knowledge or control over the jurisdiction where materials were distributed for downloading.... Defendants had in place methods to limit user access in jurisdictions where the risk of finding of obscenity was greater... They knew they had a member in Memphis." Thomas, 74 F.3d at 711. The Thomas court also pointed out that the Supreme Court, in Sable Communications v. FCC, 492 U.S. 115, 125-26 (1989), "found no constitutional impediment" in requiring distributors of adult content to tailor their materials to the standards of a particular community. Thomas, 74 F.3d at 712 . 
media-neutrality of laws of general application. The knowing transmission of sexual content from California to Tennessee via the Internet is no different from sending it by mail. The same is true of Internet gambling: Although setting up a casino or bookmaking operation in cyberspace requires more sophistication than running a sports-betting operation by telephone or mail, the underlying crimes are identical, whatever the medium.

There are, undoubtedly, Internet-specific crimes that can be attacked only in a media-specific manner. When a computer system is itself the subject or object of a crime, the offense is subject to media-specific laws. ${ }^{246}$ For example, a crime such as hacking into a credit card computer system and using the information to obtain fraudulent credit cards is punishable, not by media neutral laws, but by specific federal statutes that cover computer crimes. ${ }^{247}$ The same laws thwarted a scheme by a hacker named Eugene Kashpureff to divert Internet traffic that was intended for InterNICregistered Web sites (domain names ending in ".com," ".net," ".org," etc.) to his own "AlterNIC" domains (".sex" and ".web"). ${ }^{248}$

Concerning Internet gambling, however, as Professor Hardy notes in a different context, "[t]here is nothing about the connection medium itself that matters here or that differs from other communication means. ${ }^{3249}$ Indeed, given the broad language of $\S 1084$, which prohibits the use of any wired or similarly connected communications service from being used for gambling, one can argue that the Wire Wager Act was drafted to ensure that the precise nature of the wiring used is irrelevant. This Essay concludes, therefore, that there is no reason why courts should not apply $\S 1084$ to enforce federal gambling policy on the Internet.

246. See Dillon et al., supra note 238 , at 506.

247. See, e.g., 18 U.S.C. § 1030 (1994 \& Supp. III 1998) (prescribing penalties for engaging in "[f]raud and related activity in connection with computers"); id. § 2511 (1994 \& Supp. III 1998) (prohibiting the "interception and disclosure of wire, oral, or electronic communications"); see also United States v. Peterson, 98 F.3d 502, 504 (9th Cir. 1996) (affirming the sentence of a computer hacker who pled guilty to, inter alia, violating the aforementioned statutes).

248. Dillon et al., supra note 238, at 504 n.4.

249. Hardy, supra note 17 , at 1000 (commenting that libel or copyright infringement is the same offense whether committed via e-mail, fax, or U.S. mail). 
. 